Geo-Marine Letters

October 2018, Volume 38, Issue 5, Pages 385-402

http://dx.doi.org/10.1007/s00367-018-0547-5

http://archimer.ifremer.fr/doc/00456/56737/

\title{
Gas occurrence and shallow conduit systems in the Western Sea of Marmara: a review and new acoustic evidence
} \author{
Sarıtaş Hakan ${ }^{1,}$, Çifçi Günay ${ }^{1}$, Géli Louis ${ }^{2}$, Thomas Yannick ${ }^{2}$, Marsset Bruno ${ }^{2}$, Henry Pierre ${ }^{3}$,
Grall Celine ${ }^{3}$, Rochat Alexis ${ }^{2}$
}

${ }^{1}$ Institute of Marine Sciences and Technology, SeisLab, Dokuz Eylul University, Inciralti, Izmir, Turkey

2 Ifremer - French Research Institute for Exploration of the Sea, Marine Geosciences, Plouzané, France

${ }^{3}$ CEREGE, Aix-Marseille University, CNRS, Marseille, France

* Corresponding author : Sarıtaş Hakan, email address : hakan.saritas@mta.gov.tr

\begin{abstract}
:
Based on 3D and 2D high-resolution multichannel seismic reflection data in the Western High-Sea of Marmara, this study reviews shallow gas occurrence and related structures and classifies gas conduit systems within the upper, few hundred meter-thick sediment layers below the seafloor. Acoustic anomalies including high amplitude-reverse polarity reflections (bright spots), low amplitude transparent zones, chaotic or discontinuous reflections, pull-down effects, and plumes in the water column are interpreted in terms of natural gas occurrence and fluid flow structures (e.g., mud volcanoes, pockmarks). The gas occurrence is thought to be mostly of thermogenic origin. Mud volcanoes are one of the primary gas conduits forming craters on the seabed due to overpressure of fluidized gassy sediment flows. Following the reach of the Northern Branch of the North Anatolian Fault (NAF-N) to the Western High, the thermogenic fluids are believed to migrate vertically and horizontally to shallow depths mainly through the faults. Natural gas most probably originates from the Thrace Basin Eocene source rock or the Eocene-Oligocene reservoir rock, which extends below the Western High. Shallow gas is distributed by minor faults and gas pipes. Gas, to some extent, emanates from the seafloor via pockmarks and mud volcanoes or is trapped by the crests of the anticlines coinciding with erosional surfaces, impermeable sediments, and gas hydrate-bearing layers. Shallow traps below the tectonized "Western High" structure are likely located in thin layers of sands imbedded with impermeable silty clay layers. However, there is no shallow reservoir in the usual sense within the upper layers imaged by the 3D seismic data (<300 ms two-way travel time). The existence of gas is an indicator of hydrocarbonrich layers at depth and of active tectonics, and it also impacts the global climate and marine life conditions.
\end{abstract}

Keywords : Shallowgas, Gas conduit systems, Mud volcano, Pockmark, 2D-3D seismic, Western High, Sea ofMarmara 


\section{Introduction}

Shallow-deep hydrocarbon gases and fluid flow structures in marine sediments have been investigated by geoscientists for years for a large variety of applications, including tectonic studies (e.g. Magee et al., 2015; Rensbergen et al., 2007), energy resources (e.g. Chand et al., 2012; Hornafius et al., 1999; Hovland, 1992; Milkov and Sassen, 2000), climate research (e.g. Chand et al., 2012; Milkov and Sassen, 2000), forecasting of earthquakes (e.g. Hovland et al., 2002) and marine life (e.g. Cordes et al., 2010; Levin, 2005), as well as for geohazard studies (e.g. Hovland et al., 2002; Orange et al., 2005).

After the destructive 1999 Kocaeli Earthquake by fracturing of the North Anatolian Fault (NAF) in the east of the Marmara region, a number of scientific cruises (listed in Appendix) have been carried out in the Sea of Marmara, providing evidence of fluids and free gas emissions along or near the NAF-N (Alpar, 1999; Armijo et al., 2005; Bayrakci et al., 2014; Crémière et al., 2012; Embriaco et al., 2014; Geli et al., 2008; Halbach et al., 2004; Kuşçu et al., 2008; Tryon et al., 2012). Additionally, a number of pockmarks, gas accumulations and seepages have been observed in the Southern Shelf of the Marmara Sea along the central branch of the NAF (Okay and Aydemir, 2016; Vardar and Alpar, 2016). Tectonic control of the NAF-N seems as the most significant factor for the occurrence of fluid flows (gas, oil, groundwater, brine, etc.) from shallow or deep level marine sediments to the seafloor and for gas trapping under the anticline crests in the Sea of Marmara (Armijo et al., 2005; Dupré et al., 2015; Geli et al., 2008; Kuşçu et al., 2005; Ruffine et al., 2012; Tryon et al., 2010; Tryon et al., 2012; Zitter et al., 2008). Earthquake activity may affect fluid seepages (Tryon et al. 2012). Gas samples from different locations along the NAF-N have shown that the origin of the methane is related to deep-sourced thermogenic gas production in the ridges (Bourry et al., 2009). In the Sea of Marmara, the fault planes and gas-related structures along the NAF-N zone in seepage areas may be main pathways for fluid and gas expulsions in such a strike-slip tectonic regime (Kuşçu et al., 2008). The occurrence of gas-related structures depends on tectonic movements, rapid sedimentation, continuous hydrocarbon production, and gas-charged deep sediment sections (Dimitrov, 2002).

A primary objective of this study is to review in detail the shallow gas occurrence and fluid flow structures and to classify gas conduit systems within the upper few hundred meters of the 
sedimentary section at the Western High located between the Tekirdağ Basin and the Central Basin in the Sea of Marmara. We interpret 2D and 3D multichannel seismic reflection data in terms of the amplitude response of shallow deposits (3D data was used in previous studies by; Grall et al., 2013; Thomas et al., 2012).

This study is significant because the description of gas occurrence and conduit systems is key to efficient hydrocarbon exploration, safe drilling and a better understanding of field geology. Gas existence, mud volcanoes, and pockmarks have been reported during previous scientific surveys in the Western High (e.g. Dupré et al., 2015; Grall et al., 2013; Henry and Marnaut Scientific Party, 2007; Kuşçu et al., 2008). However, there remains a paucity of evidence on the gas occurrence originating from acoustic anomalies such as bright spots, gas pipes, acoustic transparent and blanking zones. In this paper, we provide new evidence supporting the existence of gas and conduit systems from the area and more details on pockmarks and mud volcanoes. We end the paper by suggesting a model for the formation of pockmarks and a 3D model for the shallow gas occurrence including fluid flow structures, tectonic features, depositional surfaces and gas emissions.

\section{Regional setting}

\subsection{Geological Context}

The Western High is located within the Sea of Marmara in the NW of Turkey (Fig. 1). The first high-resolution bathymetric map (with node grid spacing below $100 \mathrm{~m}$ ) of the Sea of Marmara was obtained within the framework of Turkish-French cooperation (Le Pichon et al., 2001). The deeper part of the Sea of Marmara consists of four basins and two NE-SW trending highs separating these basins from each other. The basins from the west to the east are: the Tekirdag Basin (the deepest point $1125 \mathrm{~m}$ ), the Central Basin (1256 m), the Kumburgaz Basin (820 m) and the Çınarcık Basin $(1270 \mathrm{~m})$. The Western High $(420-750 \mathrm{~m})$ is a large NE-SW oriented ridge located between the Tekirdağ Basin and the Central Basin. The NAF-N cuts directly along and

divides the Western High into two parts (e.g. the Northern Western High -NoW- and the Southern Western High -SoW), and then connects with the Ganos Fault in the west (Fig. 1). 
The Western High is controlled by gravity instabilities and tectonic activity (Fig. 2), which cause regional landslides (Gökaşan et al., 2003), translational shifts, debris and mudflows (Gazioğlu et al., 2005). This high is thought to be one of the oldest and largest submarine landslides of the Sea of Marmara (Gazioğlu et al., 2005). The Early Miocene-Early Pliocene Thrace-Eskişehir fault zone has caused the Sea of Marmara to extend to the north and the south as a graben structure (Yaltırak, 2002). Then, the North Anatolian Fault Zone System (NAFZS) reached the Sea of Marmara during Pliocene times (Yaltırak, 2002) and cut the Marmara Basin in the E-W direction until it connected with the Ganos fault in the west (Gökaşan et al., 2003; Yaltırak, 2002). These tectonics have led to large mass movements of the southern margin that resulted in the formation of the Western High (Gökaşan et al., 2003). The tectonics of the Western High have been controlled mainly by the dextral strike-slip movement of the NAF over at least the last $400 \mathrm{ka}$ (Grall et al., 2013). According to the seismic data, the sediments on the southern slope of the Western High were uplifted by the active reverse faults bounded by the NAF-N (Gökaşan et al., 2003).

Bayrakci et al. (2013) carried out a tomographic investigation on the basement depth of the Sea of Marmara using ocean bottom seismometers (OBS). According to their study, the thickest section of the so-called "post-kinematics" sediment layers is located between the Central Basin and the Tekirdağ Basin, including the Western High. The basement is $6 \mathrm{~km}$ deep under the Western High, forming a large basement depression linking the Central Basin to the Tekirdağ Basin.

Hereafter, we will use the chrono-stratigraphy scale established by Grall et al. (2013), who estimated the age of the 7 main seismic horizons (noted from $\mathrm{HO}$ to H6, respectively) in correlation with the beginning of the marine isotope stages (MIS) (Table 1). In addition, we will use sedimentation rate estimates at $0.3-0.5 \mathrm{~mm} / \mathrm{yr}$ based on the identification of two tephra layers at $7 \mathrm{~m}$ and $15 \mathrm{~m}$ within a $28.8 \mathrm{~m}$ long core MD01-2430 collected during the MARMARACORE2001 cruise within the 3D-survey area (Çağatay et al., 2015; Grall et al., 2013). Armijo et al. (2005) and Crémière et al. (2012) also assumed the sedimentation rate as $0.1-0.5 \mathrm{~mm} / \mathrm{yr}$ on the ridges. 


\begin{tabular}{|c|c|c|c|c|c|c|c|c|}
\hline Horizons & H0 & H1 & H1 & H2 & H3 & H4 & H5 & H6 \\
\hline Age (ka) & 39.3 & $105 \pm 13$ & $141 \pm 11$ & $245 \pm 25$ & $340 \pm 24$ & $448 \pm 41$ & $574 \pm 46$ & $661 \pm 66$ \\
\hline MIS & Tephra & MIS 5e/d & MIS 6 & MIS 8/7 & MIS 10/9 & MIS 12 & MIS 15 & MIS 16 \\
\hline
\end{tabular}

Table 1. The horizons from H0 to H6 with their ages and the beginning of MIS on the Western High (Grall et al., 2013).

\subsection{Previous evidence for gas existence}

The Western High is a unique area in the Sea of Marmara to observe active gas emission at or near the footprint of the main strike-slip NAF-N on the seafloor and the existence of gas related structures such as mud volcanoes, pockmarks. Studies over the past two decades have provided important information on gas occurrence. The first gas expulsions into sea water related to the NAF-N were observed during the Meteor cruise M44/1 (1999) in this area (Kuşçu et al., 2008). In addition, the first 1:50000 scale bathymetric map of the Western High was obtained during this cruise (Kuşçu et al., 2008). According to previous studies in the Western High, various intensity fluid outlets and gas emissions at the seafloor (Armijo et al., 2005; Crémière et al., 2012; Dupré et al., 2015; Geli et al., 2008; Kuşçu et al.,2008; Tryon et al. 2010; Tryon et al., 2012; Zitter et al., 2008), methane-derived carbonate crusts (Crémière et al., 2012; Zitter et al., 2008), black sulphide patches on the seabed (Kuşçu et al.,2008; Tryon et al. 2010; Zitter et al., 2008), a shallow sulfate reaction zone at depths of around 5m below the seafloor (Çağatay et al., 2004; Halbach et al., 2004), benthic communities in cold seep areas (Ritt et al., 2010), and the widespread occurrence of gas (Thomas et al., 2012) were detected along the NAF-N (e.g. Judd and Hovland, 2007). Formation of gas hydrate and oil globules have been observed in core data retrieved in the vicinity of mud volcanoes (Bourry et al., 2009; Tryon et al., 2010). These findings have mainly emphasized the relationship between tectonics and gas occurrence in the Sea of Marmara including the Western High by the authors mentioned above.

\subsection{Origin of the thermogenic gas}

Bourry et al. (2009) and Ruffine et al. (2012) studied the chemical compounds of the gas bubbles and hydrate expelled from the mud volcano in the Western High. According to this, free gas and 
hydrate are composed of around $90 \%$ methane $\left(\mathrm{C}_{1}\right)$ and around $60 \%$ methane $\left(\mathrm{C}_{1}\right)$ respectively. They also contain abundances of ethane $\left(\mathrm{C}_{2}\right)$, propane $\left(\mathrm{C}_{3}\right)$, isobutene $\left(\mathrm{i}-\mathrm{C}_{4}\right)$ and carbon-dioxide $\left(\mathrm{CO}_{2}\right)$. Based on the molecular $\left(\mathrm{C}_{1} / \mathrm{C}_{2}+\mathrm{C}_{3}\right)$ and isotopic compositions $\left(\delta^{13} \mathrm{C}, \delta \mathrm{D}\right)$ of the methane contained within gas hydrate, the data analysis $\left(\mathrm{C}_{1} / \mathrm{C}_{2}+\mathrm{C}_{3}\right.$ ratio of $3.3, \delta^{13} \mathrm{C}-44.1 \%$ o PB, $\delta \mathrm{D}$ $219 \%$ SMOW) points out that gas is of thermogenic origin. The low $\delta^{13} \mathrm{C}$ value of carbon patches and concretions on and below the seafloor shows a mixture of biogenic and thermogenic gases in the Western High (Crémière et al., 2012). Typical values of thermogenic methane vary between $-20 \%$ and $-50 \%$ PDB for $\delta^{13} \mathrm{C}$ (carbon isotopic data), and $-100 \%$ and $-300 \%$ SMOW for $\delta \mathrm{D}$ (hydrogen isotopic data) (Schoell, 1988).

Depending on the same seafloor conditions (6.69 $\mathrm{MPa}$ and $\left.14.5{ }^{\circ} \mathrm{C}\right)$, the above-mentioned thermogenic gas composition is almost the same as that acquired at Kuzey Marmara-1 (K.M-1) offshore gas field (Fig. 1) (Bourry et al., 2009; Gürgey et al., 2005). The K.M-1 field is located within the boundary of the Western High, north-east of this ridge (Tryon et al. 2010, Tryon et al., 2012). Moreover, the measured methane-based hydrate composition at Western High is almost the same as the calculated hydrate composition in the study area, as well as the K.M-1 field (Bourry et al., 2009). The system (P-T conditions, gas composition and concentration) allows structure II gas hydrate to form (Bourry et al., 2009, Ruffin et al., 2012). The natural gas is produced from Middle-Upper Eocene Soğucak formation reservoir in the K.M-1 field (Gürgey et al., 2005). The gas originated from Eocene Hamitabat source rock and 90-95\% of the gas is produced by marine organic matter (Hoşgörmez and Yalçın, 2005). Ruffine et al. (2012) explained that the gas bubbles from the Western High might be genetically linked to one onshore natural gas field, which consists of Hamitabat and Mezardere formation.

\section{Methods}

\subsection{D Seismics}

The 3D high-resolution seismic data was collected in 2009. The survey area covers $3 \times 11 \mathrm{~km}^{2}$ at water depths below seafloor ranging from $~ 400$ to $800 \mathrm{~m}$ on the Western High (Fig. 1). Two source arrays consisted of two mini-GI guns $\left(24 \mathrm{inc}^{3}\right)$ at an immersion depth of $1.5 \mathrm{~m}$. Two streamers of $300 \mathrm{~m}$ in length each (group interval $=6.25 \mathrm{~m}$ ) were deployed $25 \mathrm{~m}$ apart with bin size $6.25 \times 6.25 \mathrm{~m}^{2}$ (folding $\approx 20$ ). Streamer immersion depth was $3 \mathrm{~m}$. Sail lines were $25 \mathrm{~m}$ apart 
for improved fold. The signal dominant frequency is between 80 and $150 \mathrm{~Hz}$. A total of 200000 shots were recorded along 135 east-west oriented sailing lines. The data were recorded within a 0.5-2.0 s time-window at a sampling rate of $0.5 \mathrm{~ms}$. For full description of the survey, the reader is referred to Thomas et al. (2012).

The data were processed by IFREMER's Sispeed program. Source delay corrections and bandpass filtering $(20-250 \mathrm{~Hz})$ were applied prior to main processing of the data, after which the real position of the sources and receivers were computed. Constant velocity normal move-out, 3D stacking and two-pass, constant velocity Stolt migration were applied respectively in the main processing. Velocity information was derived from 2D multichannel PirMARMARA-2010 data to use in $3 \mathrm{D}$ data, as more accurate velocity information could be obtained using a $1500 \mathrm{~m}$ streamer.

\subsection{D multichannel seismic reflection}

A total of $160 \mathrm{~km}$ of $2 \mathrm{D}$ multichannel seismic reflection dataset was collected in this area using a SeaMUX NTRS2 (Hydroscience Technologies) system in 2010 (Fig. 1).

The acquisition system comprised a $1500 \mathrm{~m}$ long offset streamer towed at an immersion depth of 3-4 m with 20 active sections @ 75 m, 6.25 m group interval (240 channel), and 13 birds. 10 of these birds were compass birds owned by Genavir/IFREMER used for the computation of the streamer's real position. One GI gun (45/45 cubic inc ${ }^{3}-2000$ psi) was towed at a distance of 20$25 \mathrm{~m}$ and an immersion depth of 2-3 $\mathrm{m}$. Shoot interval, record length and sample rate were $18 \mathrm{~m}$ (8 s), $5 \mathrm{~s}$ and 1 millisecond, respectively. Recording signal dominant frequency was around 80 $\mathrm{Hz}$.

Initially, true reflection points were calculated using bird navigation information and the geometry obtained was embedded into SEGY output. Seismic velocities were picked every 250 CDP points and were used in Kirchhoff Time Migration. 


\subsection{Reverse polarity reflections}

During the interpretation phase, the seabed layer and three reverse polarity reflections entitled respectively as $\mathrm{H} 1$ (red), H2 (green) (Fig. 3a) and BS-Bright spot (Fig. 3b) were picked in the 3D and 2D datasets (Fig. 9). These three horizons are stronger and more recognizable than the surrounding surfaces. Bright spots were revealed with envelope analysis (e.g. Taner et al., 1979; Thakur and Rajput, 2011).

The time structure and amplitude maps were generated by the interpretation of seismic "picks" across a series of 2D lines that were subsequently gridded (Busby and Pérez, 2012). Continuity of horizons $\mathrm{H} 1$ and $\mathrm{H} 2$ could not be followed under topographic reliefs such as mud volcanoes, and the southeast corner of the study area.

\subsection{Seismic evidence for gas occurrence}

Low-very low amplitude and highly disrupted reflections that occur due to a decrease in wave propagation speed have been referred to as acoustic masking by Andreassen et al. (2007). In seismic data, upward movements of gas might be characterized by sub-vertical, circular, narrow acoustic masking zones, so-called gas pipe or acoustic pipe structure (Andreassen et al., 2007; Hustoft et al., 2007). The upper limit of gas pipes mostly gives a bright spot, while underlying reflections along vertical zones may appear pulled down (e.g. Hustoft et al., 2007). In particular, gas pipes have a direct relationship with the formation of pockmarks on the seafloor caused by rapid migration of gas-charged pore fluids (e.g. Judd and Hovland, 2007; Sun et al., 2012).

Acoustic blanking is mostly observed as an invisible or faint reflection zone with an enhanced upper boundary reflector (Schroot and Schüttenhelm, 2003). It may be caused by, i) absorption of seismic energy in overlying gas-charged sediments, ii) shallow fluid flows which locally make deposit units transparent, iii) presence of a hard sediment reflecting seismic energy (Missiaen et al., 2002; Schroot and Schüttenhelm, 2003), iv) presence of the gas hydrate zone above the bottom simulating reflector (BSR) (e.g. Kim et al., 2016; Lee and Dillon, 2001)

The gas-related structures; e.g. mud volcanoes and pockmarks are detected by their morphological shape in the seismic section. Mud volcanoes are in the form of positive dome- 
shaped structures due to upward migration of low-density gassy material; on the contrary, pockmarks are V-shaped depression structures (Judd and Hovland, 2007; Somoza et al., 2003). The intrusion zones of the material are generally seen on the seismic section as a nearly unreflective, masked and/or chaotic appearance directly beneath the upper boundary of mud volcanoes and mud diapirs (e.g. Ben-Avraham et al., 2005; Chen et al., 2014; Somoza et al., 2012; Xing and Spiess, 2015). The mud volcanoes are described as extrusion systems. They remove the material from their crater vents to the seabed. Intensive gas seepage to the water column, and termed gas plumes are mostly identified on top of mud volcanoes and pockmarks (e.g. Greinert et al., 2006; Rovere et al., 2014). The observation of a pockmark formation in an area is interpreted as current or past fluid-gas escapes to the water column (e.g. Andreassen et al., 2007; Cathles et al., 2010; Garcia-Gil et al., 2002; Judd and Hovland 2007; Somoza et al., 2003).

\section{Results}

\subsection{Gas occurrence and bright spots}

We provide a layer called BS, which is made up of bright spots and is not a correlative surface or horizon. The BS layer appears as a non-homogeneous, discontinuous, and reverse polarityenhanced acoustic anomaly reflection. The depth of this layer is variable and observed in the uppermost $300 \mathrm{~m}$ of the sedimentary column, but it is usually found in shallow depths ranging between 60 and $100 \mathrm{~m}$. The BS layer may be below the H2 horizon or may jump up and down between the $\mathrm{H} 1$ and $\mathrm{H} 2$ horizons. It forms part of the $\mathrm{H} 1$ and $\mathrm{H} 2$ horizons where the reflections are of high amplitude and opposite polarity. The BS layer is found widely across the study area. In the 3D seismic zone, the area covered by this layer (dark green to green) is approximately $7.195 \mathrm{~km}^{2}$ (Fig. 6). Although the shape of the BS layer is seen as partly parallel to seafloor bathymetry, it also has an irregular shape in some places where the stratification shows complex dipping reflections. Since the distribution of 2D seismic data is uneven, we cannot clearly map the BS layer outside the 3D seismic zone.

The BS layer is usually located around or above mud volcanoes, pipes, pockmarks, faults, and below anticlines. Detectability of the sediment layers decreases beneath the BS layer. They occur as discontinuous and unreflective acoustically transparent zones beneath the anticlines and monocline, suggesting the presence of gas (Fig. 7, 9a). In the envelope of seismic data, these 
transparent zones appear as acoustic blanked areas terminated at high-amplitude anomaly reflection viewing as dark black patches (Fig. 7, 9b). This patchy boundary commonly coincides with an erosional surface which can absorb the seismic energy by dissolved gas or bubbles trapped just beneath this surface (Fig. 9b). The erosional surface most probably played a role of as a cap rock for gas trapping. When the gas reaches this surface, it usually tends to migrate laterally (Fig. 9b). The reason for acoustic anomalies may originate from thermogenic gas production at a deeper level causing overpressure and from biogenic gas produced at the shallow level (e.g. Sun et al., 2012). The vertically extended wide blanking areas below the anticlines may even also suggest upward migration of gas caused by conduit systems, such as buried mud volcanoes, mud diapirs (Fig. 9b).

Dissolved gas in pore water in subsurface sediments reduces seismic velocities (Lee et al., 1993). Thus, reflections may appear to be pulled down where the very-low amplitude transparent zone anomaly develops below the BS layer (Cyan oval in Fig. 9a).

The reflection segments of high seismic amplitudes (bright spots) can be observed at different shallow stratigraphic levels, but they are more commonly detected along H2 than along H1 (Fig. 3) (see also Thomas et al., 2012). High amplitude values along $\mathrm{H} 2$ appear on both sides of the main fault, forming alignments trending mainly in E-W direction on the southern flank and in $\mathrm{N}$ E and SW-NE directions on the northern flank (Fig. 5). However, the amount of the gas causing acoustic anomalies was not able to be detected.

\subsection{Gas conduit systems}

\subsubsection{Faults}

The studying of faults is of great importance to understand gas/fluid migration and accumulation systems in the subsurface (e.g. Hustoft et al., 2007; Judd and Hovland, 2007; Tryon et al., 2010; $\mathrm{Xu}$ et al., 2011). The faults for gas migration in the Western High are handled as two classes; deep-seated faults and near-surface faults.

The deep-seated NAF-N and its Riedel faults can be imaged up to a depth of about $750 \mathrm{~m}$ below the seabed (Fig. 9). However, it cannot be observed in the data whether these faults reach the 
basement high or source/ reservoir rock. Occurrences of natural gas seepages along the NAF-N zone in the Western High indicate that there is a clear association between gas migration and the NAF-N (Fig. 6). Acoustically transparent-low frequency anomaly zones are encountered on both sides of this fault. The mud volcano field which is one of the vertically extended transparent zones occurs just north of the NAF-N (Fig. 7, 8, 9).

The shallow normal faults are observed within the BS layer zone and upper part of the anticlines. The fault traces were notably revealed on the time-structure maps of the H1, H2 horizons, and the seafloor (Fig. 2, 4). The dextral strike-slip NAF-N led to the formation of common NW-SE trending normal faults on both sides of the plate boundary (Fig. 4). In addition, there is a SW-NE arc-shaped normal fault cluster in the SW of the 3D area. The data clearly show that the bright spots and acoustic anomalies in the shallow zone are usually placed around these shallow normal faults along the NAF-N zone, indicating the occurrence of gas (Fig. 4-9) (e.g. Cartwright et al., 2007; Løseth et al., 2009).

\subsubsection{Mud Volcanoes}

A mud intrusion zone has been imaged in the Western High. This vertically extensive zone was divided into 3 feeder channels around $1.1 \mathrm{~s}$ (TWT) and formed a mud complex that consisted of 3 mud volcanoes, one of which is buried. (Fig. 8, 9). We name this complex "Erkan Gökaşan" after an important Turkish marine geologist.

The mud volcano crater nearest the NAF-N is circular (shown by a white star in Fig.8), and approximately $80 \mathrm{~m}$ in diameter. The topographic height of the crater with irregular rim is up to $9.5 \mathrm{~m}$ relative to the surrounding area. The next mud volcano (shown by black star in Fig.8) vent is approximately $58 \mathrm{~m}$ in diameter. Its maximum topographic relief is almost $6 \mathrm{~m}$. The buried mud volcano of about $300 \mathrm{~m}$ width is at a depth of $37.5 \mathrm{~m}$ below the seabed. It splits into two chimneys around $0.94 \mathrm{~s}$ (TWT). Chaotic reflections of the overlying sediment are caused by ongoing gas emission, taking the shape of the crater during deposition. The existence of the gas and disturbed sediments along the feeder channel (intrusion zone) gave a seismically transparentchaotic view (Fig. 8) (e.g. Somoza et al., 2003). Outside the intrusion zone, reflections are characterized by continuous, undisturbed reflections. The connection between the mud volcanoes and the NAF-N are illustrated in Figure 11. The accumulated sediment thickness between flanks 
of the mud volcanoes (white and black stars in Fig. 8) is about $22.5 \mathrm{~m}(0.90-0.93 \mathrm{~s}$ TWT), given that the last eruption occurred at less than $75 \mathrm{ka}$ and that the sedimentation rate is $\geq 300 \mathrm{~m} / \mathrm{m}$. $\mathrm{y}$. Interestingly, we found a horizontal very weak amplitude reflection anomaly, approximately 25 $\mathrm{m}$ below the mud volcano vent. This reflection could be a bottom simulation reflector (BSR) due to gas hydrate occurrence.

Mud volcanoes seem to be active seep sites because intensive gas seeps into the water column were acoustically detected as gas plumes immediately above, with strong bright spot reflections suggesting gas occurrence below (Fig. 7). Since the data resolution is insufficient to interpret below 1.7 seconds (TWT), the root of the mud intrusion zone and its penetration to the main gas reservoir cannot be brought to light.

\subsubsection{Pockmarks}

Pockmark-related depressions on the seabed were observed newly in this work at eighteen locations in the area (Fig. 2b, 7a, 9a). The occurrence of the pockmarks ranged from $607 \mathrm{~m}$ to $735 \mathrm{~m}$ water depths. In general, pockmarks were between 25 and $120 \mathrm{~m}$ in diameter with pit depths in the range $1-15 \mathrm{~m}$. Although shapes of the pockmarks are not uniform, they are generally circular. According to Hovland et al. (2002), these are included in the "normal pockmark" class depending on the shape and size. In 2D seismic data, it cannot be understood clearly whether these depressions (Fig. 9a) are pockmarks or not, but these seafloor depressions coincide with the upper termination of gas pipe (brown vertical zones in Fig. 9a), and thus, they are noted to be pockmarks.

As illustrated in Fig. 6, most pockmarks in the area coincide with gas emissions (Dupré et al., 2015). It shows possible active pockmarks, which are considered to have a major role in expelling gas into the water. Gas pipes match with nearly all pockmarks locations (Fig. 7). Down-bending reflections on horizon $\mathrm{H} 1$ beneath pockmark P3 suggest the presence of the paleopockmark. It means that pockmark activation started at least around $105 \mathrm{ka}$ in the PlioPleistocene. The surface of the paleo-pockmark was covered with $15 \mathrm{~m}$ sediment. There was an up-bending reflection under the P2 pockmark, indicating a gas accumulation phase for a new eruption in the near future (Fig. 7). Although the top of the pockmarks has normal polarity, an enhanced and reverse polarity reflection occurs beneath the P2 and P3 pockmarks (Fig 7a). 


\subsubsection{Gas Pipes}

Almost transparent sediment reflections with very low amplitude resembling a thin pipe were observed in this work due to the fluid flow between sediments. The lower boundaries of the pipes in the study area were observed around $0.95-1.05 \mathrm{~s}$ (TWT) and root from acoustic blanking zones (Fig. 7, 9). The tendency of shallow gases to migrate upwards is considered to play an important role in the formation of gas pipes. The length of the pipes is around $60 \mathrm{~m}$ in vertical scale. The pull-down effects also observed within some pipes originated from gas-related low velocity (Fig. 7, 9).

Gas pipe locations frequently matched with pockmarks (Fig. 7, 9). Cartwright and Santamarina (2015) have proposed that the upper boundaries of gas pipes coincide with pockmarks or paleopockmarks. For the Western High area, under the P2 pockmark, two pipes could be detected, one of which had entirely acoustic masking (Fig 7). The upper limit of this pipe appeared as enhanced steeply up-bending reflection. Below the P3 pockmark, another gas pipe created an acoustic masked zone between $0.86-0.95$ s. (TWT) (Fig 7).

\section{Discussion}

\subsection{Shallow gas occurrence}

According to the results of this study, the seismic data confirm the widespread shallow gas occurrence (Fig. 9, 6), supporting previous results on free gas emission from the seafloor, fluid flow and gas hydrate formation in the Sea of Marmara (see Section 2.2 above). The data also provide evidence of focused fluid flow pathways such as mud volcanoes, gas pipes and faults in shallow sediments.

Apart from bright spots (BS layer), $\mathrm{H} 1$ is also of negative polarity. Nearly all points of the layer appear to be of unvarying phase and amplitude, except for some small areas (Fig. 3, 5). This character is not related to the presence of gas (Thomas et al., 2012), but presumably to the sedimentary structure (see Section 3.3). H1 probably represents a hard lacustrine/marine transition boundary in between lacustrine laminated mud above (Çağatay et. al., 2015) and marine sapropel deposition below (Grall et al., 2016). Both the amplitude and phase values of $\mathrm{H} 2$ 
vary laterally in a wide negative scale depending more likely on gas intensity (Fig. 3, 5), and probable lithological alteration. Bright spot anomalies are mostly observed on the H2 layer and erosional surfaces (Fig. 9). These results are consistent with Thomas et al. (2012) findings for H1 and H2. BS is much more important in this study with respect to gas occurrence because it is thought to represent the upper boundary of the gas accumulation.

This study has been unable to accurately define the limits of gas existence in shallow sediment. However, on the basis of 3D data, we can infer that one of the main gas occurrence zones is most likely located along the E-W anticline in the south of the NAF-N (Fig 5, 6,7), while the other main gas occurrences, based on 2D data, are located along anticline zones on the northern block of the NAF-N (Fig. 9). A possible explanation for this might be that gas accumulation zones can occur typically near the top of anticlines which act as barriers to migration. This finding was also reported by Thomas et al. (2012). Different methods and analysis are needed to calculate the volume of gas in sediments, such as AVO, analyses of sediment cores, well-log velocity and resistivity (Tréhu et al., 2004). In future studies, a 3D seismic survey conducted over all the Western High would yield better results for the observation of gas presence.

\subsection{Mud volcanoes}

Owing to the fact that the NAF-N has an extensional regime in the area, the required main overpressure for occurrence of submarine mud volcanoes cannot be linked to compressional tectonic that is reported as one of the main factors for mud volcano formation in some areas, contrarily (e.g. Dimitrov, 2002; Judd and Hovland, 2007; Milkov 2000). It is quite likely that high pressure is mainly caused by buoyancy forces of fine-grained sediments with pore-fluids, similar to that documented by Shi and Wang, (1985). However, the rapid sedimentation rate (Dimitrov, 2002; Milkov 2000) and shallow faults in the main strike-slip zone may locally provoke restraining and squeezing behavior. Our hypothesis is that when the NAF-N reached the Marmara Basin as a master fault in the Middle-Late Miocene, it most probably cut the oil-gas reservoir or source rock overlain by a thick sediment succession in the Western High. The gassaturated semi-liquid material has moved vertically upward by its buoyancy along the deepseated the NAF-N from a high pressure to low-pressure zone and create a mud volcano. Furthermore, extensional forces believably induced mud volcano formation by weakening the 
overburden by fracturing and thinning it (Chen et al., 2014; Dimitrov, 2002; Jackson and Vendeville, 1994).

The low amplitude reflection interpreted as BSR is observed at roughly $25 \mathrm{~m}$ below the mud volcano crater. This finding is consistent with that of Bourry et al. (2009) who calculated the thickness of the gas hydrate stability zone at the mud volcano area at around $100 \mathrm{~m}$ between the seafloor $\left(14.5^{\circ} \mathrm{C}-6.69 \mathrm{MPa}\right)$ and the base of the gas hydrate zone $\left(19{ }^{\circ} \mathrm{C}-7.84 \mathrm{MPa}\right)$. Thus, it intimates that a link may exist between gas hydrate occurrence and mud volcanoes in the area. Taken together, the results suggest that mud volcanoes are excellent conduits for gas distribution and gas escape into the sea column.

\subsection{Development of pockmarks}

Pockmarks are expected to consist of three stages; before blow-out (fluid-gas has been collecting under the seafloor over the years), during blow-out (fluid-gas accumulation can cause overpressure and erupts abruptly), after blow-out (pockmark may remain active or inactive as fluid-gas emission, or may enter a dormant period) (e.g. Hovland and Judd 1988; Duarte et al., 2017)

We would like to discuss the development process of a pockmark in the study area (illustrated in Fig. 10).

1) The deep generated gas in the Western High (Bourry et al., 2009) is presumed to ascend upwards by the NAF-N and through the mud volcanoes (Tryon et al. 2010) and is potentially terminated in shallow depths by the crest of the buried mud volcano or erosional surfaces.

2) Then the thermogenic methane-rich fluids which probably mix with biogenic gas in this level can pass upward through permeable/semi-permeable sediments (Fig. 10a).

3) The fluids, which could be delivered vertically over tens of meters for millions of years by gas pipes, may gather beneath the impermeable seafloor strata and cause increasing gas pressure. When the accumulated gas pressure initiates to exceed the sum of water pressure at the seafloor and the atmospheric pressure at the sea surface a temporal mound may begin to rise on the seafloor (e.g. Judd and Hovland, 2007), (Fig. 10b-c). 
4) This overpressure can cause a state of static instability and a decrease in the shear strength of the surrounded sediment (Hovland and Judd 1988). The cover sediment cannot withstand this excessive pressure, resulting in a possible devastating blowout, and a slump occurs on seafloor morphology (Fig. 10d).

\subsection{A model for shallow gas occurrence}

Based on 3D seismic data, we suggest a model for shallow gas occurrence originating from deep and shallow microbial reactions in sediments (Fig. 11). Nevertheless, an exact confirmation for the deep gas occurrence and deep conduits in this study is not possible in the absence of adequate seismic data with sufficient resolution, collected with seismic streamers of appropriate length.

The journey of gas towards the seafloor could be as follows.

1) Thermogenic gas, which probably originated from deep reservoir and/or source rock, can firstly migrate vertically into shallow areas mainly along the NAF-N. In the reviewing literature, the NAF-N and related strike-slip faults are thought to form main lines connecting with the deep located gas source in the Western High (Geli et al., 2008; Kuşçu et al., 2005; Ruffine et al., 2012; Zitter et al., 2008). Bourry et al. (2009) proposed that the NAF-N penetrates through or originates from Upper-Middle Eocene reservoir rock or Eocene source rock. The mud volcanoes and deep-seated normal faults, which may reach reservoir rock, also most probably play a significant role as conduits for thermogenic gas migration to the shallow depth in the area (e.g. Sun et al. 2012). With regard to recent data on gas-hydrate samples from the mud volcano area, it is clearly identified that the composition of thermogenic gas has close similarities to that obtained from the K.M-1 natural field (Bourry et al., 2009, Ruffin et al., 2012).

2) In the shallow zone, natural gas (thermogenic, biogenic, or a mixture of both) could be distributed vertically and horizontally through minor faults, pipes, permeable and semipermeable sediments. Brittle fault zones can provide efficient pathways for deep-seated gas bearing fluids (Caine et al., 1996).

3) Thus, it may not only accumulate beneath impermeable deposits such as erosional surfaces (e.g. Andreassen et al., 2007), and below anticline crests but it may also reach the seafloor and is emitted through venting systems such as minor faults, fractures, 
pockmarks and mud volcanoes. The echosounder data show that gas emissions (Dupré et al., 2015) exist not only above the faults, pockmarks and the mud volcano area but also above the gas-charged sediments (e.g. Judd et al., 2002; Judd and Hovland, 2007).

This model can be a key for understanding shallow gas occurrence and conduit systems in the Western High. It will also help to avoid unforeseen geohazards during drilling processes, such as blow-outs, submarine landslides and surficial slumps.

\section{Conclusions}

According to this review, the following conclusions can be drawn;

- The abundance of acoustic anomalies, such as bright spots, gas pipes, plumes in the water column, acoustic transparent zones, and gas-related structures, like pockmarks, or mud volcanoes point out widespread gas occurrence within the shallow $(<300 \mathrm{~m})$ sediment across the study area.

- The gas in the shallow zone is distributed horizontally and vertically through minor faults, mud volcanoes, erosional surfaces, and sediment pore space. It is trapped by erosional surfaces, anticline crest and impermeable layers.

- Gas emissions to the water column are transported by faults, fractures, pockmarks, and mud volcanoes. Ongoing gas seepage activity shows that the area is still active.

- The formation of pockmarks seems to be related to the upward migration of biogenic and thermogenic gas mixing in shallow sediments.

- The horizons with reverse polarity-enhanced reflection do not always recommend evidence of gas occurrence below. The transition between lacustrine and marine environment can cause bright spot reflection in seismic data.

- The formation of mud volcanoes is mainly controlled by buoyancy forces related to fluidized gassy sediments causing overpressure in the source or reservoir rock. The NAF-N movement leads to transform solid sediment into a brittle form along the zone. This event also contributes to gas-related edifices rising upward

The Western High has become a significant area for studying relations between seismicity and fluid activity in recent years. More detailed studies and analyses would be beneficial to reveal the hydrocarbon potential of the Western High. 


\section{Acknowledgments}

We would like to express our gratitude Captain and crew of R/V Le Suroît (IFREMER- 3D seismic) and R/V K.Piri Reis (D.E.U- 2D seismic). We also thank the Genavir seismic team for support in both surveys. The support of the Turkish coast guards of the Sea of Marmara was also very valuable. We would like to thank, Livio Ruffine and Stéphanie Dupré for fruitful exchanges. We are also grateful to Alison Chalm for the final language editing of the paper. Data were gathered thanks to the Scientific team of the IFREMER and to the Seislab team of the Institute of Marine Sciences and Technology - Dokuz Eylül University (Izmir). The Marmesonet and PirMarmara cruises were supported by ESONET NoE, Network of Excellence, coordinated by IFREMER, D.E.U, I.T.U and co-funded by EU, Project no: 036851 (2009 and 2010).

\section{Appendix. Scientific cruises in the Sea of Marmara}

Meteor Cruise 1999, MARM2000, MARM2001, MARMACORE 2001, MARMARASCARPS 2002, MARMARA-VT 2004, MARNAUT 2007, TAMAM 2008, Marmara 2009, MARMESONET 2009, PirMarmara 2010, Marmara 2010, SoMAR 2013, Marsite 2014.

\section{References}

Alpar, B. (1999). Underwater signatures of the Kocaeli earthquake of 17 August 1999 in Turkey, Turk. J. Mar. Sci. 5, 111-130.

Amante, C., Eakins, B.W., 2009. ETOPO1 1 Arc-Minute Global Relief Model: Procedures, Data Sources and Analysis. NOAA Technical Memorandum NESDIS NGDC-24. National Geophysical Data Center, NOAA. doi: 10.7289/V5C8276M.

Andreassen, K., Nilssen, E. G., Ødegaard C. M., 2007. Analysis of shallow gas and fluid migration within the Plio-Pleistocene sedimentary succession of the SW Barents Sea continental margin using 3D seismic data. Geo-Marine Letters 27, 155-171. doi: 10.1007/s00367-007-0071-5.

Armijo, R., Pondard, N., Meyer, B., Uçakuş, G., Lepinay, B.M., Malavieille, J., Dominguez, S., Gustcher, M.A., Beck, C., Çağatay, N., Çakir, Z., İmren, C., Eriş, K., Natalin, B., Özalaybey, S., Tolun, L., Lefevre, I., Seeber, L., Gasperini, L., Rangin, C., Emre, O., Sarikavak, K., 2005. Submarine fault scarps in the Sea of Marmara pull-apart (North Anatolian Fault): Implications for seismic hazard in Istanbul. Geochemistry Geophysics Geosysttems, 6, 1-29. doi: 10.7289/V5C8276M.

Bayrakci, G., Laigle, M., Bécel, A., Hirn, A., Taymaz, T., Yolsal-Çevikbilen, S., Seismarmara team, 2013. 3-D sediment-basement tomography of the Northern Marmara trough by a dense 
OBS network at the nodes of a grid of controlled source profiles along the North Anatolian fault. Geophysical Journal International 194, 1335-1357. doi: 10.1093/gji/ggt211.

Bayrakci, G., Scalabrin, C., Dupré, S., Leblond, I., Tary, J.-B., Lanteri, N., Augustin J.-M., Berger, L., Cros, E., Ogor, A., Tsabaris, C., Lescanne M., Géli L., 2014. Acoustic monitoring of gas emissions fron the seafloor. PartII: a case study from the Sea of Marmara. Marine Geophysical Research, 35, 221-229. doi: 10.1007/s11001-014-9227-7.

Ben-Avraham, Z., Reshef, M., Smith, G., 2005. Seismic Signature of Gas Hydrate and Mud Volcanoes of the South African Continental Margin. Mud Volcanoes, Geodyn. Seism. 1727. doi:10.1007/1-4020-3204-8_2.

Bourry, C., Chazallon B., Charlou J.L., Donval J.P., Ruffine L., Henry P., Géli L., Çağatay M.N., İnan S., Moreau M., 2009. Free gas and gas hydrates from the Sea of Marmara, Turkey: Chemical and structural characterization. Chemical Geology 264, 197-206. doi: 10.1016/j.chemgeo.2009.03.007.

Busby, C., Pérez A.A., 2012. Tectonics of Sedimentary Basins: Recent Advances. WileyBlacwell. doi: 10.1002/9781444347166.

Caine, J.S., Evans, J.P., Forster, C.B., 1996. Fault zone architecture and permeability structure. Geology 24, 1025-1028. doi: 10.1130/0091-7613(1996)024<1025:FZAAPS>2.3.CO;2.

Çağatay, M., Ozcan, M., Gungor, E., 2004. Pore-water and sediment geochemistry in the Marmara Sea (Turkey): Early diagenesis and diffusive fluxes, Geochemistry Exploration Environmental Analysis, 4(3), 213-225. doi:10.1144/1467-7873/04-202.

Çagatay, M. N., Wulf, S., Sancar, Ü., Özmaral, A., Vidal, L., Henry, P., Appelt, O., Gasperini, L., 2015. The tephra record from the Sea of Marmara for the last ca. $70 \mathrm{ka}$ and its palaeoceanographic implications, Marine Geology 361, 96-110. doi:10.1016/j.margeo.2015.01.005.

Cartwright, J., Huuse, M., Aplin, A., 2007. Seal bypass systems. Aapg Bulletin 91, 1141-1166. doi: 10.1306/04090705181.

Cartwright, J., Santamarina, C., 2015. Seismic characteristics of fluid escape pipes in sedimentary basins: Implications for pipe genesis. Marine and Petroleum Geology 65, 126-140. doi: 10.1016/j.marpetgeo.2015.03.023.

Cathles, L.M., Su, Z., Chen, D., 2010. The physics of gas chimney and pockmark formation, with implications for assessment of seafloor hazards and gas sequestration. Marine and Petroleum Geology 27, 82-91. doi: 10.1016/j.marpetgeo.2009.09.010.

Chand, S., Thorsnes, T., Rise, L., Brunstad, H., Stoddart, D., Bøe, R., Lågstad, P., Svolsbru, T., 2012. Multiple episodes of fluid flow in the SW Barents Sea (Loppa High) evidenced by gas flares, pockmarks and gas hydrate accumulation. Earth Planet. Sci. Lett. 331-332, 305-314. doi:10.1016/j.epsl.2012.03.021. 
Chen, S.C., Hsu, S.K., Wang, Y., Chung, S.H., Chen, P.C., Tsai, C.H., Liu, C.S., Lin, H.S., Lee, Y.W., 2014. Distribution and characters of the mud diapirs and mud volcanoes off southwest Taiwan. J. Asian Earth Sci. 92, 201-214. doi:10.1016/j.jseaes.2013.10.009.

Cordes, E. E., Cunha, M. R., Galéron, J., Mora, C., Olu-Le Roy, K., Sibuet, M., Van Gaever, S., Vanreusel, A., Levin, L. A., 2010. The influence of geological, geochemical, and biogenic habitat heterogeneity on seep biodiversity. Marine Ecology 31, 51-65. doi: 10.1111/j.14390485.2009.00334.x.

Crémière, A., Pierre, C., Blanc-Valleron, M., Zitter, T., Çağatay, M. N., Henry, P., 2012. Methane-derived authigenic carbonates along the North Anatolian fault system in the Sea of Marmara (Turkey). Deep Sea Research Part I: Oceanographic Research Papers 66, 114-13. doi: 10.1016/j.dsr.2012.03.014.

Çiftçi, N. B., Bozkurt, E., 2009. Pattern of normal faulting in the Gediz Graben, SW Turkey. Tectonophysics 473, 234-260. doi: 10.1016/j.tecto.2008.05.036.

Dimitrov, L.I., 2002. Mud volcanoes - the most important pathway for degassing deeply buried sediments. Earth-Science Reviews 59, 49-76. doi: 10.1016/S0012-8252(02)00069-7.

Duarte, D., Magalhaes, V.H., Terrinha, P., Ribeiro, C., Madureira, P., Pinheiro, L.M., Benazzouz, O., Kim, J., Duarte, H., 2017. Identification and characterization of fluid escape structures ( pockmarks) in the Estremadura Spur, West Iberian Margin 82, 414-423. doi:10.1016/j.marpetgeo.2017.02.026.

Dupré, S., Scalabrin, C., Grall, C., Augustin, J. M., Henry, P., Şengör, A. M. C., Görür, N., Çağatay, M. N., Géli, L., 2015. Tectonic and sedimentary controls on widespread gas emissions in the Sea of Marmara: Results from systematic, shipborne multibeam echo sounder water column imaging. Journal of Geophysical Research: Solid Earth 120, 28912912. doi:10.1002/2014JB011617.

Garcia-Gil, S., Vilas, F., Garcia-Garcia, A., 2002. Shallow gas features in incised-valley fills (Ria de Vigo, NW Spain): a case study. Continental Shelf Research 22, 2303-2315. doi: 10.1016/S0278-4343(02)00057-2.

Gazioğlu, C., Yucel, Z.Y., Dogan, E., 2005. Morphological features of major submarine landslides of Marmara Sea using multibeam data. Journal of Coastal Research 21, 664-673. doi: 10.2112/03-0060.1.

Géli, L., Henry, P., Andre, C., Zitter, T., Çağatay, N., Mercier de Lepinay, B., LePichon, X., Sengor, A.M.D., Gorur, N., Natalin, B., Ucarkus, G., Ozeren, S., Volker, D., Gasperini, L., Bourlanger, S., MarNaut Scientific Party, 2008. Gas emissions and active tectonics within the submerged section of the North Anatolia Fault zone in the Sea of Marmara. Earth and Planetary Science Letters 274, 34-39. doi: 10.1016/j.eps1.2008.06.047.

Gökaşan, E., Ustaömer, T., Gazioğlu, C., Yücel, Z.Y., Öztürk, K., Tur H., Ecevitoğlu, B., Tok, B., 2003. Morpho-tectonic evolution of the Marmara Sea inferred from multi-beam 
bathymetric and seismic data. Geo-Marine Letters 23, 19-33. doi: 10.1007/s00367-003-01207.

Grall, C., Henry, P., Tezcan, D., de Lepinay, B. M., Bécel, A., Géli, L., Rudkiewicz, J., Tiphanie, Z., Harmegnies, F., 2012. Heat flow in the Sea of Marmara Central Basin: Possible implications for the tectonic evolution of the North Anatolian fault.Geology 40, 3-6. doi: 10.1130/G32192.1.

Grall, C., Henry, P., Thomas, Y., Westbrook, G.K., Çağatay, M.N., Marsset, B., Saritas, H., Çifçi, G., ve Geli, L., 2013. Slip rate estimation along the western segment of the Main Marmara Fault over the last 330 ka by correlating Mass Transport Deposits. Tectonics 32, 1587-1601. doi: 10.1002/2012TC003255.

Grall, C., Henry, P., Kendé, J., Çağatay, M.N., Eriş, K.K., Paillès, C., Sorlien, C., Shillington, D., McHugh, C., Steckler, M., Çifçi, G., Géli, L., 2016. Marine-to-lacustrine transition, mud volcanism, and slope instability in an active tectonic setting: the MIS 5 to 4 transition in the Sea of Marmara, Turkey 18, 11085. EGU2016 Geophysical Research Abstracts 18, 11085.

Greinert, J., Artemov, Y., Egorov, V., De Batist, M., McGinnis, D., 2006. 1300-m-high rising bubbles from mud volcanoes at $2080 \mathrm{~m}$ in the Black Sea: Hydroacoustic characteristics and temporal variability. Earth Planet. Sci. Lett. 244, 1-15. doi:10.1016/j.eps1.2006.02.011.

Gürgey, K., Philp, R.P., Clayton, C., Emiroğlu, H., Siyako, M., 2005. Geochemical and isotopic approach to maturity/source/mixing estimations for natural gas and associated condensates in the Thrace Basin, NW Turkey. Applied Geochemistry 20, 2017-2037. doi: 10.1016/j.apgeochem.2005.07.012.

Embriaco, D., Marinaro, G., Frugoni, F., Monna, S., Etiope, G., Gasperini, L., Polonia, A., Del Bianco, F., Çağatay, M.N., Ulgen, U.B., Favali, P. (2014). Monitoring of gas and seismic energy release by multiparametric benthic observatory along the North Anatolian Fault in the Sea of Marmara (NW Turkey). Geophysical Journal International 196 (2):850866.

Halbach, P., Holzbecher, E., Reichel, T., Moche, R., 2004. Migration of the sulphatemethane reaction zone in marine sediments of the Sea of Marmara-can this mechanism be tectonically induced? Chemical Geolology 205, 73-82. doi: 10.1016/j.chemgeo.2003.12.013.

Hall, J., Aksu, A.E., King, H., Gogacz, A., Yaltırak, C., Çifçi, G., 2014, Miocene-Recent evolution of the western Antalya Basin and its linkage with the Isparta Angle, eastern Mediterranean. Marine Geology 349, 1-23. doi: 10.1016/j.margeo.2013.12.009.

Henry, P., Marnaut Scientific Party, 2007. Marnaut Cruise Report. MarNaut Cruise of R/V L'Atatlante Report. Available at: http://p.f.henry.free.fr/marmara/marnaut_public/marnaut_final_reports/MARNAUT_report.p df 
Hornafius, J. S., Quigley, D., Luyendyk, B. P., 1999. The world's most spectacular marine hydrocarbon seeps (Coal Oil Point, Santa Barbara Channel, California): Quantification of emissions. Journal of Geophysical Research: Oceans 104, 20703-20711. doi: 10.1029/1999JC900148.

Hoşgörmez, H., Yalçın, M.N., 2005. Gas-source rock correlation in Thrace basin, Turkey. Marine and Petroleum Geology 22, 901-916. doi: 10.1016/j.marpetgeo.2005.04.002.

Hovland, M., 1992. Hydrocarbon Seeps in Northern Marine Waters: Their Occurrence and Effects. PALAIOS 7, 376-382. doi: 10.2307/3514823.

Hovland, M., Gardner, J. V, Judd, A.G., 2002. The significance of pockmarks to understanding fluid flow processes and geohazards. Geofluids 2, 127-136. doi:10.1046/j.14688123.2002.00028.x.

Hovland, M., Judd, A.G., 1988. Seabed Pockmarks and Seepages. Impact on Geology, Biology and the Marine Environment. Graham \& Trotman Ltd., London, 293 pp. doi: 10.13140/RG.2.1.1414.1286.

Hustoft, S., Mienert, J., Bünz, S., Nouzé, H., 2007. High-resolution 3D-seismic data indicate focussed fluid migration pathways above polygonal fault systems of the mid-Norwegian margin. Marine Geology 245, 89-106. doi:10.1016/j.margeo.2007.07.004.

Jackson, M.P., Vendeville, B., 1994. Regional extension as a geologic trigger for diapirism. Geological Society of America Bulletin 106, 57-73. doi:10.1130/00167606(1994)106<0057:REAAGT>2.3.CO;2.

Judd, A.G., Hovland, M., Dimitrov, L., Garcia Gil, S., Jukes, V., 2002. The geological methane budget at continental margins and its influence on climate change. Geofluids 2, 109-126. doi: 10.1046/j.1468-8123.2002.00027.x.

Judd, A.G., Hovland, M., 2007. Seabed fluid flow, the impact on geology, biology and the marine environment. Cambridge University Press: New York.

Kim, K.-J., Yi, B.-Y., Kang, N.-K., Yoo, D.-G., 2016. Reservoir characterization of gas hydrate in the Northwestern part of the Ulleung Basin, East Sea. Marine Georesources and Geotechnology 35, 1-10. doi:10.1080/1064119X.2016.1139644.

Kuşçu, I., Halbach, P., Inthorn, M., Kuhn, T., Seifert, R., (2008). The R/V meteor cruise leg M44/1 in February 1999 in the sea of Marmara: The first multibeam bathymetric study and analysis of methane in sediment and water columns. Turkish J. Earth Sci. 17, 461-480.

Kuşçu, İ., Okamura, M., Matsuoka, H., Gökaşan, E., Awata, Y., Tur, H., Şimşek, M., Keçer, M., 2005. Seafloor gas seeps and sediment failures triggered by the August 17, 1999 earthquake in the eastern part of the Gulf of İzmit, Sea of Marmara, NW Turkey. Marine Geology 215, 193214. doi: 10.1016/j.margeo.2004.12.002. 
Le Pichon, X., Şengör, A.M.C., Demirbağ, E., Rangin, C., İmren, C., Armijo, R., Görür, N., Çağatay, N., Mercier, B., Lepinay, M., Meyer, B., Saatçılar, R., Tok, B., 2001. The Active Main Marmara Fault. Earth and Planetary Science Letters 192, 595-616. doi: 10.1016/S0012821X(01)00449-6.

Lee, M.W., Hutchinson, D.R., Dillon, W.P., Miller, J.J., Agena, W.F., Swift, B.A., 1993. Method of estimating the amount of in situ gas hydrates in deep marine sediments. Marine and Petroleum Geology 10, 493-505. doi: 10.1016/0264-8172(93)90050-3.

Lee, M.W., Dillon, W.P., 2001. Amplitude blanking related to the pore-filling of gas hydrate in sediments. Marine Geophysics Research 22, 101-109. doi:10.1023/A:1010371308699.

Levin, L.A., 2005. Ecology of cold seep sediments: interactions of fauna with flow, chemistry and microbes. Oceanography and Marine Biology - An Annual Review, 43. Crc PressTaylor \& Francis Group, Boca Raton pp. 1-46.

Løseth, H., Gading, M., Wensaas, L., 2009. Hydrocarbon leakage interpreted on seismic data. Marine and Petroleum Geology 26, 1304-1319. doi: 10.1016/j.marpetgeo.2008.09.008.

Magee, C., Duffy, O.B., Jackson, C.A., Magee, C., Duffy, O.B., Purnell, K., Bell, R.E., Jackson, C.A., Reeve, M.T., 2015. Fault-controlled fluid flow inferred from hydrothermal vents imaged in 3D seismic reflection data offshore NW Australia Fault-controlled fluid flow inferred from hydrothermal vents imaged in 3D seismic reflection data, offshore NW Australia. doi:10.1111/bre.12111.

Milkov, A.V. (2000). Worldwide distribution of submarine mud volcanoes and associated gas hydrates. Marine Geology 167 (1-2):29-42. doi:10.1016/S0025-3227(00)00022-0

Milkov, A. V., Sassen, R., 2000. Thickness of the gas hydrate stability zone, Gulf of Mexico continental slope. Mar. Pet. Geol. 17, 981-991. doi:10.1016/S0264-8172(00)00051-9.

Missiaen, T., Murphy, S., Loncke, L., Henriet, J.P., 2002. Very high-resolution seismic mapping of shallow gas in the Belgian coastal zone. Continental Shelf Research 22, 2291-2301. doi:10.1016/S0278-4343(02)00056-0.

Okay, A., Kaşlilar Ö. A., İmren, C., Boztepe, G. A., Demirbağ, E., Kuşçu, I., 2000. Active faults and evolving strike-slip basins in the Marmara Sea, northwest Turkey: a multichannel seismic refection study. Tectonophysics 321, 189-218. doi: 10.1016/S0040-1951(00)00046-9

Okay, S., Aydemir, S., Seval 2016. Control of active faults and sea level changes on the distribution of shallow gas accumulations and gas-related seismic structures along the central branch of the North Anatolian Fault, southern Marmara shelf, Turkey. Geodinamica Acta 28, 328-346. doi: 10.1080/09853111.2016.1183445.

Orange, D. L., Garcia-Garcia, A., McConnell, D., Lorenson, T., Fortier, G., Trincardi, F., Can, Emrah., 2005. High-resolution surveys for geohazards and shallow gas: NW Adriatic (Italy) and Iskenderun Bay (Turkey). Marine Geophysical Researches 26, 247-266. doi: 
Parke, J.R., Minshull, T.A., Anderson, G., White, R.S., McKenzie, D., Kuşçu, I., Bull, J.M., Görür, N., Şengör, C., 1999. Active faults in the Sea of Marmara, Western Turkey, imaged by seismic reflection profiles. Terra Nova 11, 223-227. doi: 10.1046/j.13653121.1999.00248.x.

Rensbergen, P. Van, Rabaute, A., Colpaert, A., Ghislain, T.S., Mathijs, M., Bruggeman, A., 2007. Fluid migration and fluid seepage in the Connemara field, porcupine basin interpreted from industrial 3D seismic and well data combined with high-resolution site survey data. Int. J. Earth Sci. 96, 185-197. doi:10.1007/s00531-005-0021-2.

Ritt, B., Sarrazin, J., Caprais, J.C., Noël, P., Gauthier, O., Pierre, C., Henry, P., Desbruyères, D., 2010. First insights into the structure and environmental setting of cold-seep communities in the Marmara Sea. Deep. Res. Part I Oceanogr. Res. Pap. 57, 1120-1136. doi:10.1016/j.dsr.2010.05.011.

Rovere, M., Gamberi, F., Mercorella, A., Rashed, H., Gallerani, A., Leidi, E., Marani, M., Funari, V., Pini, G.A., 2014. Venting and seepage systems associated with mud volcanoes and mud diapirs in the southern Tyrrhenian Sea. Marine Geology 347, 153-171. doi:10.1016/j.margeo.2013.11.013.

Ruffine, L., Fandino, O., Etoubleau, J., Chéron, S., Donval, J.-P., Germain, Y., Ponzevera, E., Guyader, V., Dennielou, B., Etiope, G., Gasperini, L., Giovanni, B., Henry, P., Grall, C., Namik, Ç. M., Jean-Luc, C., Louis, G., 2012. Geochemical Dynamics of the Natural-Gas Hydrate System in the Sea of Marmara, Offshore Turkey. Advances in Natural Gas Technology, Dr. Hamid Al-Megren (Ed.), InTech. doi: 10.5772/36343.

Schoell, M., 1988. Multiple origins of methane in the earth. Chemical Geology 71, 1-10. doi: 10.1016/0009-2541(88)90101-5.

Schroot, B.M., Schüttenhelm, R.T.E., 2003. Expressions of shallow gas in the Netherlands North Sea. Geologie en Mijnbouw/Netherlands Journal of Geosciences 82, 91-105. doi: 10.1017/S0016774600022812.

Seeber, L., Cormier, M. H., McHugh, C., Emre, O., Polonia, A., Sorlien, C., 2006. Rapid subsidence and sedimentation from oblique slip near a bend on the North Anatolian transform fault in the Marmara Sea, Turkey. Geology 34, 933-936. doi: 10.1130/G22520a.1.

Shi, Y., Wang, C., 1985. High pore pressure generation in sediments in front of the Barbados Ridge complex. Geophsyical Research Letters 12, 773-776. doi: 10.1029/GL012i011p00773.

Somoza, L., Medialdea, T., León, R., Ercilla, G., Vázquez, J.T., Farran, M., Hernández-Molina, J., González, J., Juan, C., Fernández-Puga, M.C., 2012. Structure of mud volcano systems and pockmarks in the region of the Ceuta Contourite Depositional System (Western Alborá n Sea). Mar. Geol. 332-334, 4-26. doi:10.1016/j.margeo.2012.06.002. 
Somoza, L., Díaz-del-Río, V., León, R., Ivanov, M., Fernández-Puga, M.C., Gardner, J.M., Hernández-Molina, F.J., Pinheiro, L.M., Rodero, J., Lobato, a., Maestro, a., Vázquez, J.T., Medialdea, T., Fernández-Salas, L.M., 2003. Seabed morphology and hydrocarbon seepage in the Gulf of C??diz mud volcano area: Acoustic imagery, multibeam and ultra-high resolution seismic data. Mar. Geol. 195, 153-176. doi:10.1016/S0025-3227(02)00686-2.

Sorlien, C.C., Akhun, S.D., Seeber, L., Steckler, M., Shillington, D.J., Kurt, H., Çifçi, G., Poyraz, D.T., Gürçay, S., Dondurur, D., İmren, C., Perinçek, E., Okay, S., Küçük, H.M., Diebold J.B., 2012. Uniform basin growth over the last 500ka, North Anatolian Fault, Marmara Sea, Turkey. Tectonophysics 518- 521, 1-16. doi: 10.1016/j.tecto.2011.10.006.

Sun, Q., Wu, S., Cartwright, J., Dong, D., 2012. Shallow gas and focused fluid flow systems in the Pearl River Mouth Basin, northern South China Sea. Marine Geology 315-318, 1-14. doi:10.1016/j.margeo.2012.05.003.

Taner, M. T., Koehler, F., Sheriff, R. E., 1979. Complex seismic trace analysis. Geophysics 44, 1041-1063. doi: 10.1190/1.1440994.

Thakur, N. K., Rajput, S., 2011. Exploration of gas hydrates: Geophysical techniques. Springer Science \& Business Media. doi: 10.1007/978-3-642-14234-5.

Thomas, Y., Marsset, B., Westbrook, G.K., Grall, C., Géli, L., Henry, P., Çifçi, G., Rochat, A., Saritas, H., 2012. Contribution of high-resolution 3D seismic near-seafloor imaging to reservoir-scale studies: application to the active North Anatolian Fault, Sea of Marmara. Near Surface Geophysics 10, 291-301. doi: 10.3997/1873-0604.2012019.

Tréhu, A.M., Flemings, P.B., Bangs, N.L., Chevallier, J., Gràcia, E., Johnson, J.E., Liu, C.S., Liu, X.L., Riedel, M., Torres, M.E., 2004. Feeding methane vents and gas hydrate deposits at south Hydrate Ridge. Geophysical Research Letters 31, L23310. doi: 10.1029/2004GL021286.

Tryon, M., Henry, P., Çağatay, M., Zitter, T., Geli, L., Gasperini, L., Burnard, P., Bourlange, S., Grall, C., 2010. Pore fluid chemistry of the North Anatolian Fault Zone in the Sea of Marmara: a diversity of sources and processes. Geochem. Geophys. Geosyst. 11 (Q0AD03), 1-22. doi: 10.1029/2010GC003177.

Tryon, M., Henry, P., Hilton, D., 2012. Quantifying submarine fluid seep activity along the North Anatolian Fault zone in the Sea of Marmara. Marine Geology 315, 15-28. doi: 10.1016/j.margeo.2012.05.004.

Vardar, D., Alpar, B., 2016. High-resolution seismic characterization of shallow gas accumulations in the Southern Shelf of Marmara Sea, Turkey. Acta Geophysica, 64, 589609, doi: 10.1515/acgeo-2015-0059.

Xing, J., Spiess, V., 2015. Shallow gas transport and reservoirs in the vicinity of deeply rooted mud volcanoes in the central Black Sea. Mar. Geol. 369, 67-78. doi:http://dx.doi.org/10.1016/j.margeo.2015.08.005. 
Xu, G., Ma, R., Gong, D., Zhou, D., Li, J., Guo, Y., Yuan, H., Wu, C. (2011). Features of the fault system and its relationship with migration and accumulation of hydrocarbon in Liaodong Bay. Pet. Sci. 8, 251-263. doi:10.1007/s12182-011-0142-0

Yaltirak, C., 2002. Tectonic evolution of the Marmara Sea and its surroundings. Marine Geology 190, 493-529. doi: 10.1016/S0025-3227(02)00360-2.

Zitter, T.A.C., Henry, P., Aloisi, G., Delaygue, G., Çağatay, M.N., de Lepinay, B.M., Al-Samir, M., Fornacciari, F., Tesmer, M., Pekdeger, A., Wallmann, K., Lericolais, G., 2008. Cold seeps along the main Marmara Fault in the Sea of Marmara (Turkey). Deep-Sea Research 55, 552-570. doi: 10.1016/j.dsr.2008.01.002. 


\section{Figures}

Fig. 1. Shaded bathymetry and topography of Turkey and the Sea of Marmara from a compilation of GEBCO-data (Amante and Eakins, 2009). a: Simplified tectonic map of Turkey (Okay et al., 2000, Hall et al., 2014, Çiftçi and Bozkurt, 2009). Red rectangle shows the Sea of Marmara region "b". NAF: North Anatolian Fault. EAF: East Anatolian Fault. b: Active tectonic map of the Sea of Marmara region. NAF-N: Northern strand of NAF; NAF-S: Southern strand of NAF (Seeber et al., 2006). Black bold line represents the NAF-N; and in thin black lines other segments of the NAF (Sorlien et al., 2012; Grall et al., 2012; Okay et al., 2000; Parke et al., 1999, Çağatay et al., 2015). TEFZ: Thrace-Eskisehir Fault Zone (Yaltırak, 2002). K.M-1: Kuzey Marmara-1 well. Red rectangle represents the study area "c". c: Bathymetric map of the Western High. The 3D high resolution MARMESONET-2009 seismic area is shown as a thin blue rectangle $\left(3 \times 11 \mathrm{~km}^{2}\right)$. 2D PirMARMARA-2010 seismic lines are shown as thin white lines (line names: $a 2$ b1,.., a2 b10). East-West trending right lateral strike-slip NAF-N in white dashed line (Le Pichon et al., 2001). The Western High is split into two parts by the NAF-N; NoW: Northern Western High; SoW: Southern Western High. TB: Tekirdağ Basin; CB: Central Basin. Dashed black rectangle shows location of Fig. 2 a.

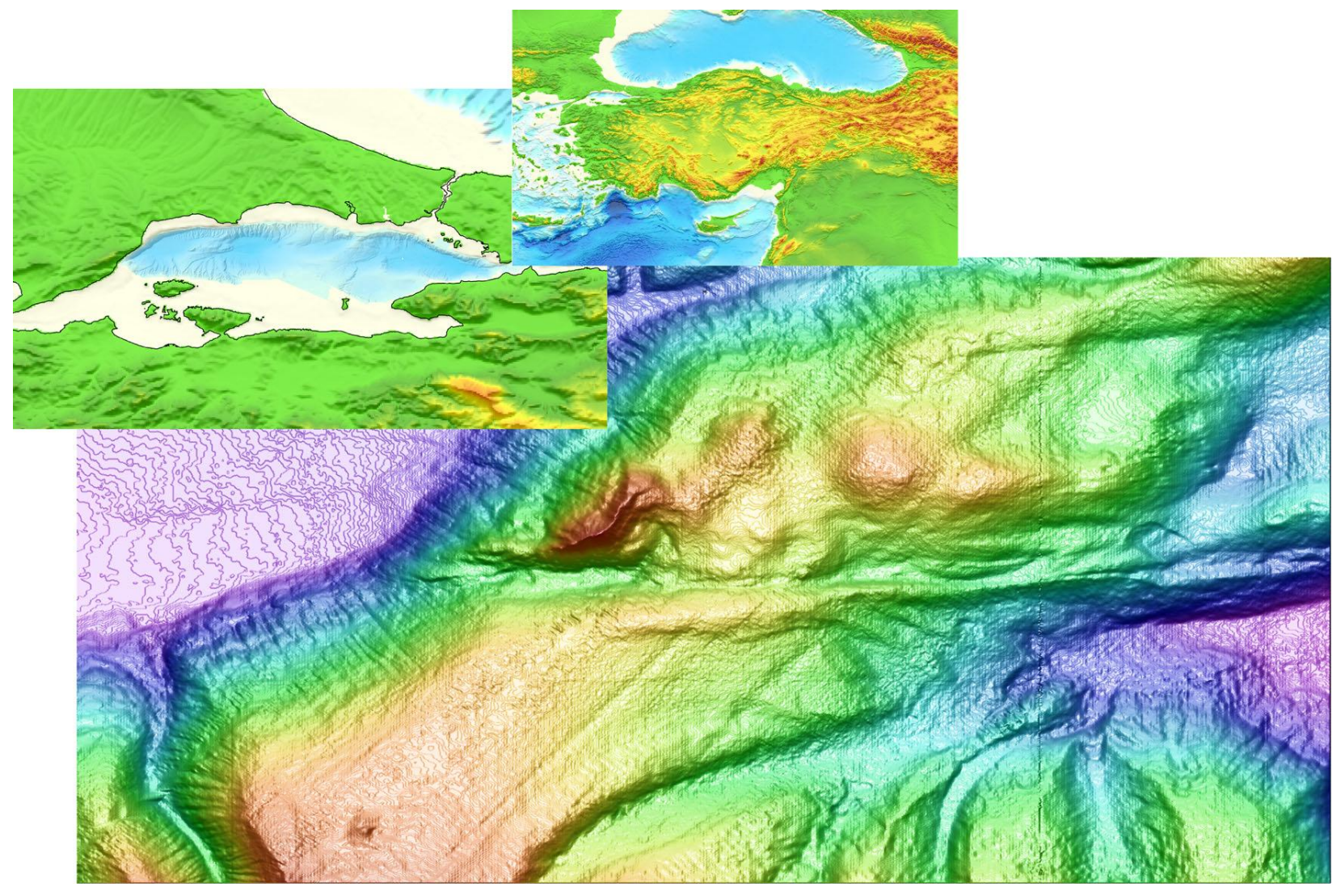


Fig. 2. a: The main faults and folded structures are designated on the Western High bathymetry based on Grall et al., (2013). Gas emissions to the water column detected by EM 302 echosounder system in Marmesonet Leg-1 cruise (Dupré et al., 2015) are shown by red points. b: Shaded relief of the seabed bathymetry of the 3D seismic area produced via picked seabed layer. c: The rough rock ridge. $\mathbf{d}$ : NE-SW trending mud volcano area. $\mathrm{c}$ and $\mathrm{d}$ maps were acquired from AUV data during Marmesonet Leg-1 cruise.

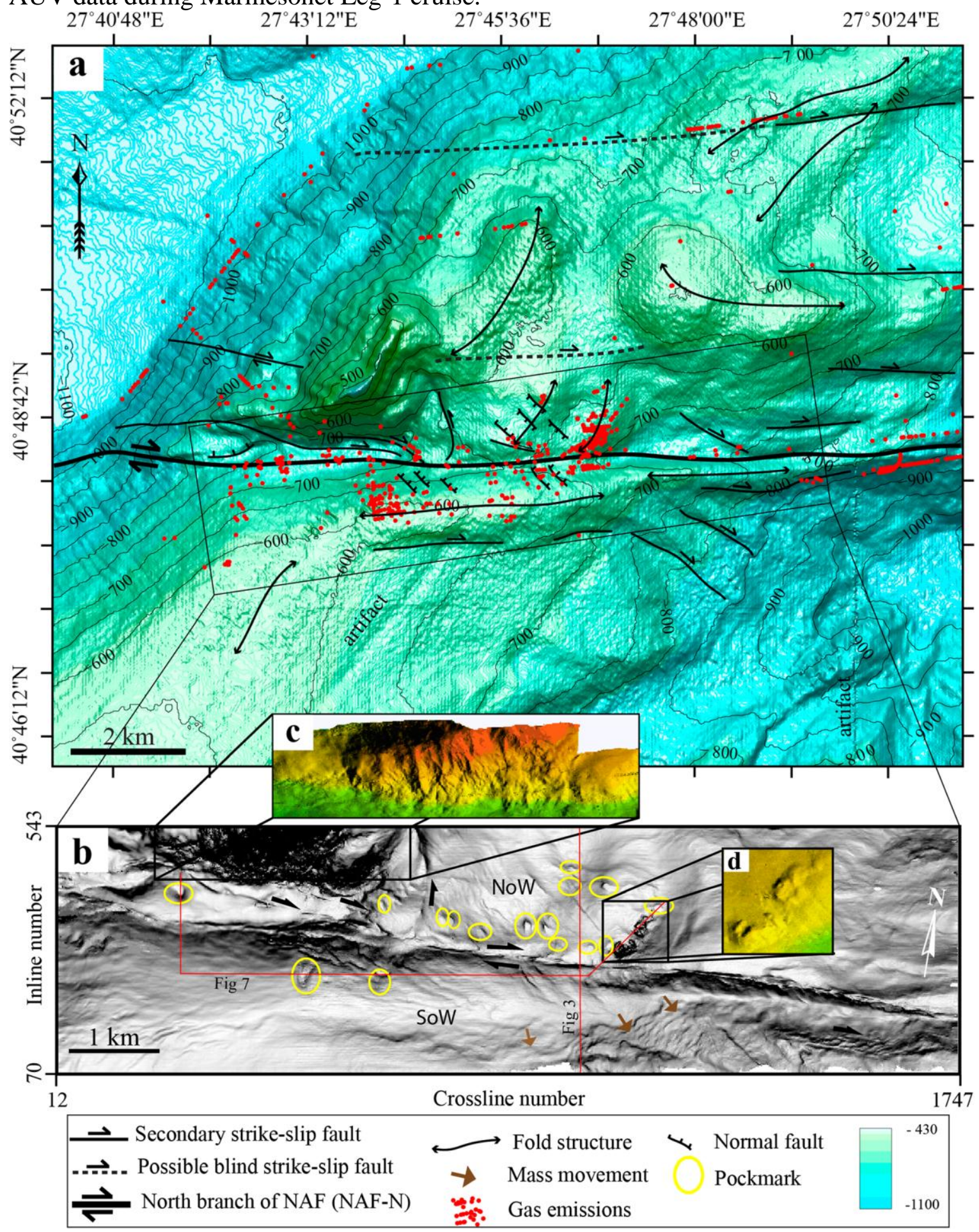


Fig. 3. Reverse polarity reflectors $\mathrm{H} 1$ (red), H2 (green) and BS (yellow) picked in 3D seismic section in two-way travel time (TWT) as second (s). The figure of a (crossline number: 1000) shows these picked layers. b: bright spots(BS) which jump up and down between $\mathrm{H} 1$ and $\mathrm{H} 2$ horizonsThe small rectangle black boxes represent the polarity of the layers and seabed.

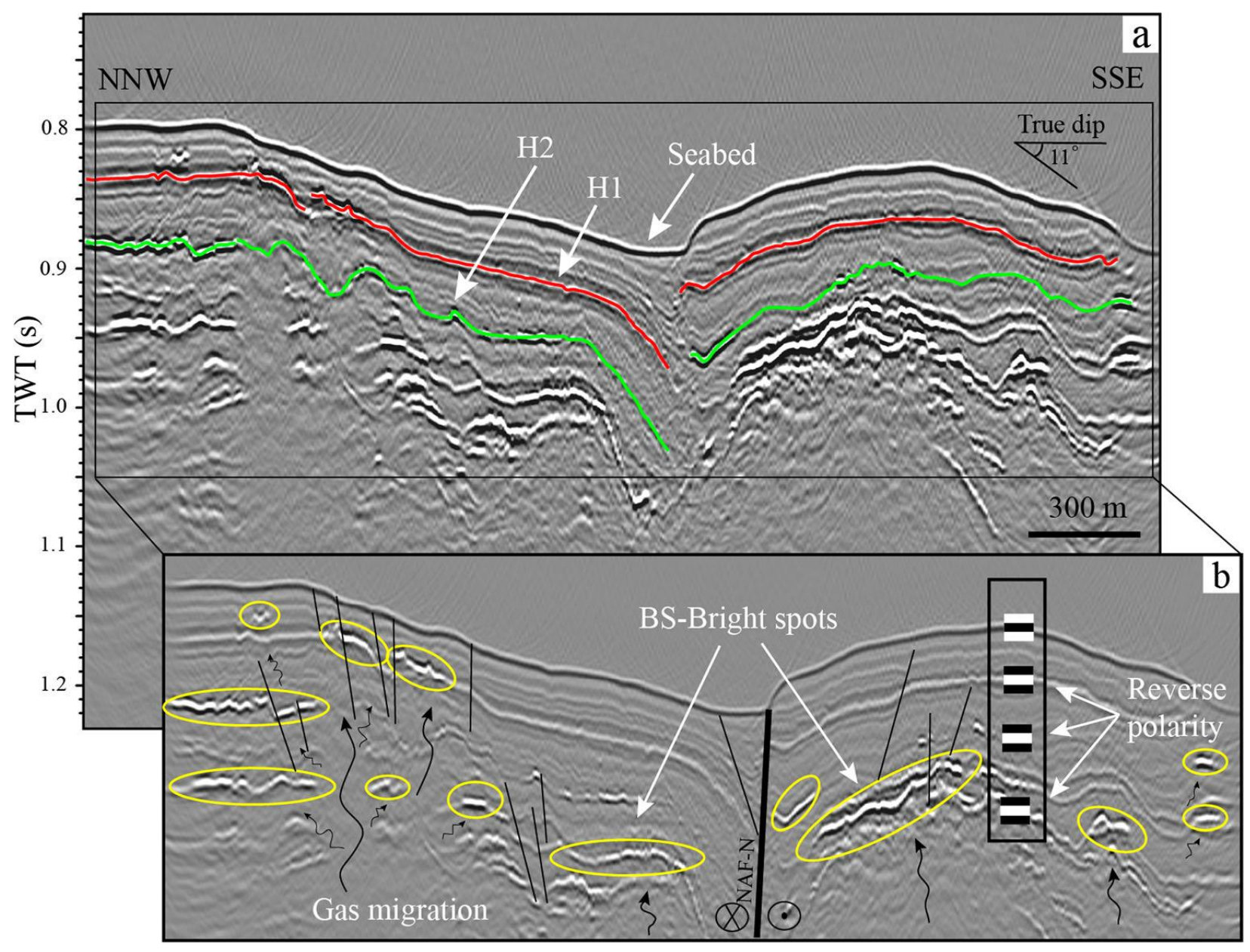


Fig. 4. Depth of $\mathrm{H} 1$ and $\mathrm{H} 2$ horizons on 3D data. The black boxes cover areas with normal faults formed in the NAF-N zone (black dashed line). $\mathrm{H} 2$ resolution is not as good as $\mathrm{H} 1$ due to poor continuity. The red box represents the mud volcano area. This area appears as a gap due to the lack of any detected strata under the mud volcano vents.
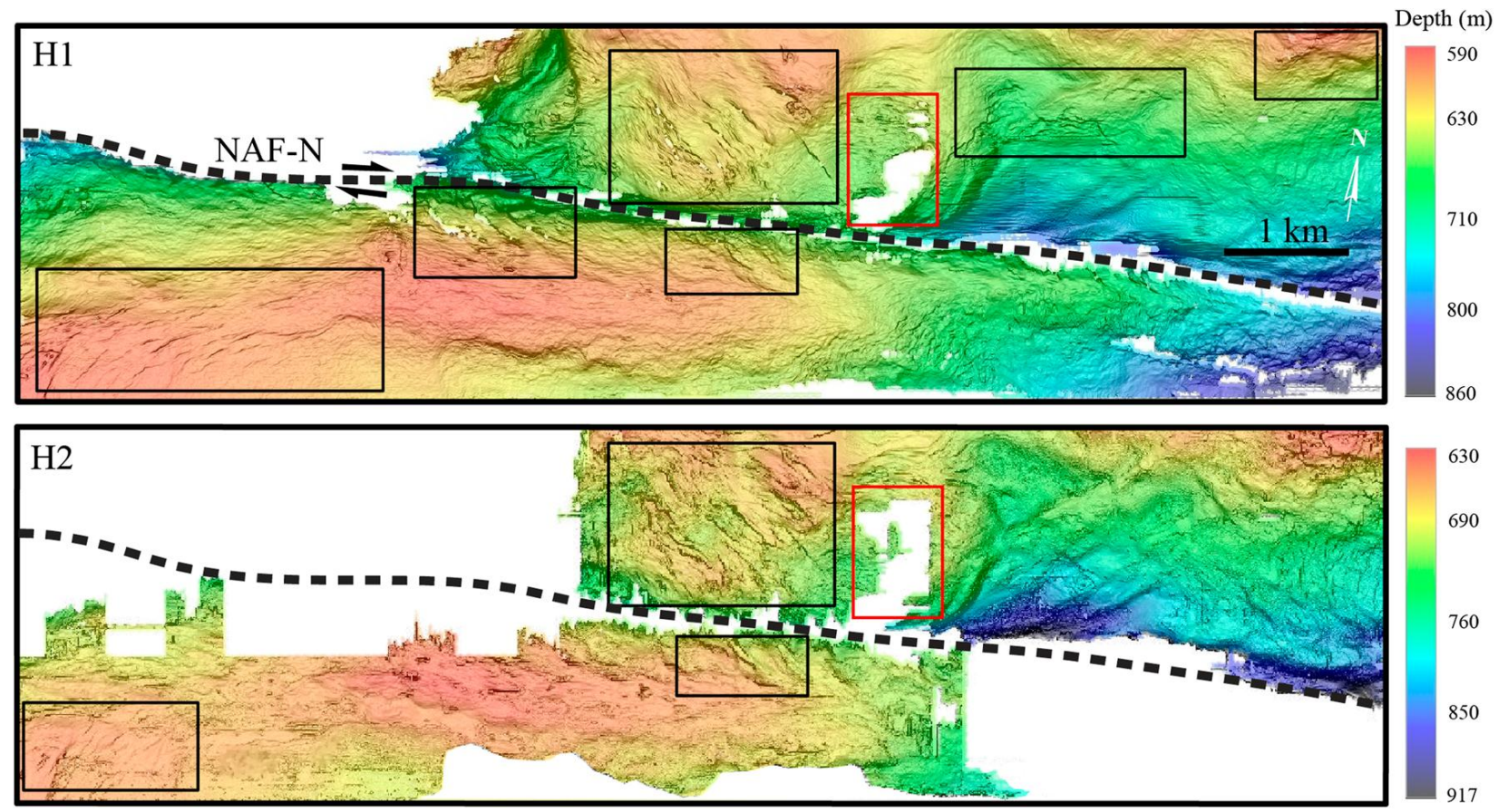
Fig. 5. Amplitude map of $\mathrm{H} 1$ and $\mathrm{H} 2$ in $3 \mathrm{D}$ data. These two layers have reverse polarity compared to the seabed (Fig. 3). In very small points, as an exception, the maps show positive amplitude values because some positive amplitude layers intersect with $\mathrm{H} 1$ and $\mathrm{H} 2$ layers. The amplitude values vary with the presence of gas. Enhanced reflection evidence is coded from yellow to pink in the color bar. Gas accumulations are mainly sustained by faults represented as black lines in this figure. $\mathrm{H} 2$ has much more bright spots than $\mathrm{H} 1$, especially in the crest of anticlines (Fig. 2). There is significant gas accumulation in the south of the NAF-N (Thomas et al., 2012).
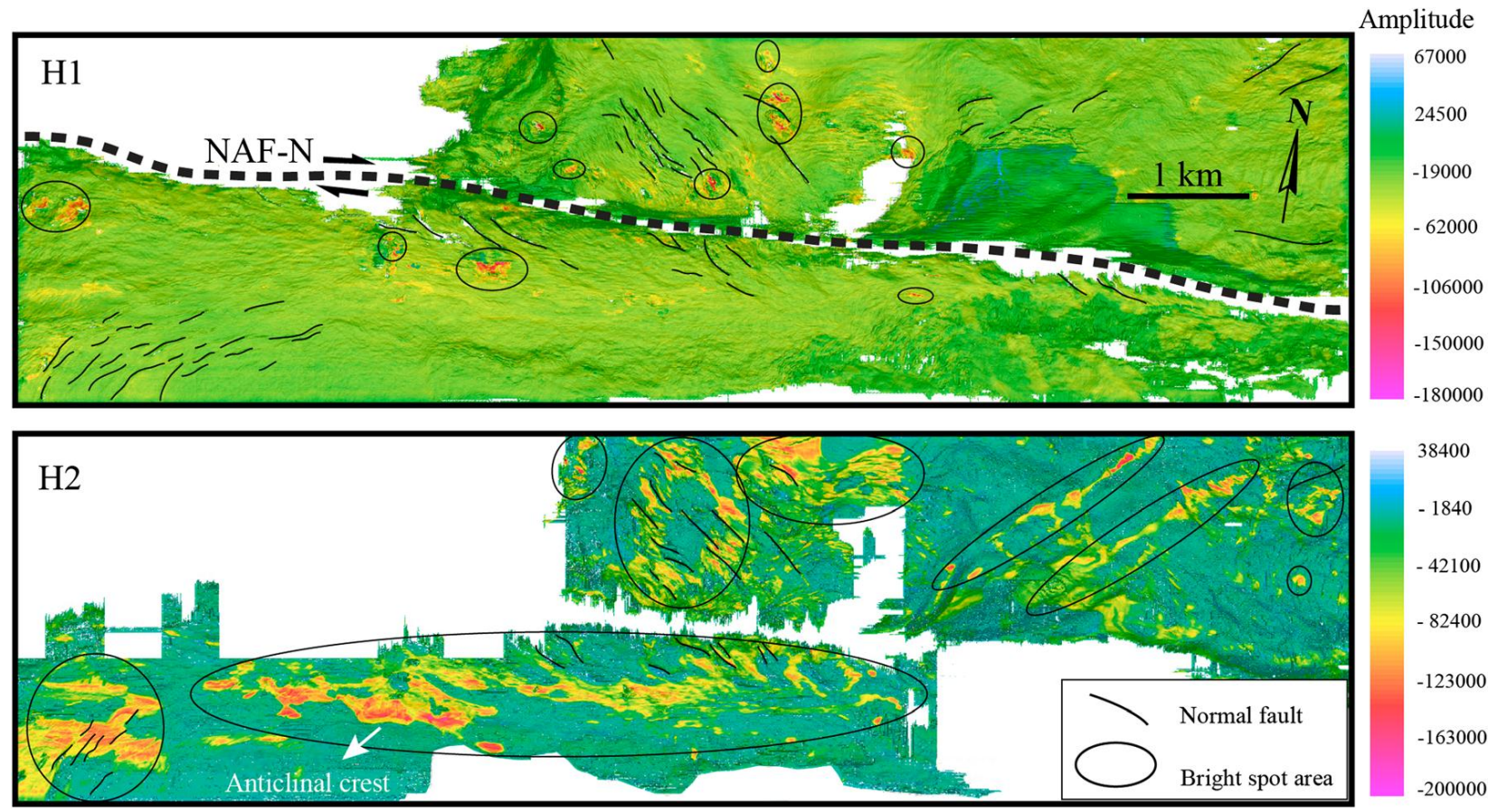
Fig. 6. Locations of the bright spots in the 3D area. Regardless of layer continuity, the BS was picked on envelope analysis of the seismic data (Fig. 7). The negative amplitudes of bright spots are converted to positive in this analysis. Dark blue color represents the highest amplitude value that is generally accumulated at the crest of the E-W trending anticline in the south of the NAF$\mathrm{N}$. The black lines represent faults. White color represents non-bright spot fields. Yellow dots show gas emissions to the water column (Dupré et al., 2015). Mud volcanoes, pockmarks and faults generally coincide with gas emissions and/or bright spots, suggesting that they are potential conduits for horizontal and vertical gas flow in shallow depths.

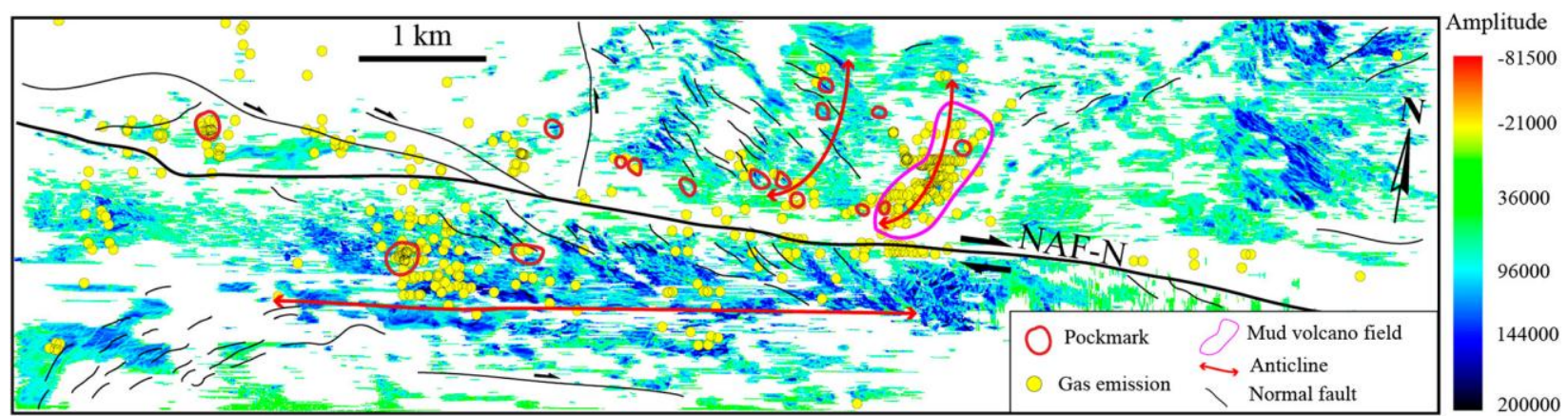


Fig. 7. The arbitrary line was drawn over the pockmarks, E-W anticline and mud volcanoes. See Fig. $2 \mathrm{~b}$ for location. The top figure shows bright spots as yellow-green color. Gas flows (black wave arrows) toward the seafloor and is trapped close to the NAF-N (A-B) by the anticlines (BC) and the mud volcanoes (C-D). Intensive gas seepage into the water column is represented as a gas plume gives high backscatter on the seismic profile (black star), and is observed at the top of the pockmarks (red star) and mud volcanoes. The source of gas is mainly thermogenic formation coming from deep level (Bourry et al., 2009). Gas pipes coincide with pockmarks. The bottom figure is the envelope analysis of the seismic line. The black layer (pointed with red arrows) indicates bright spots; BS is detected more accurately.

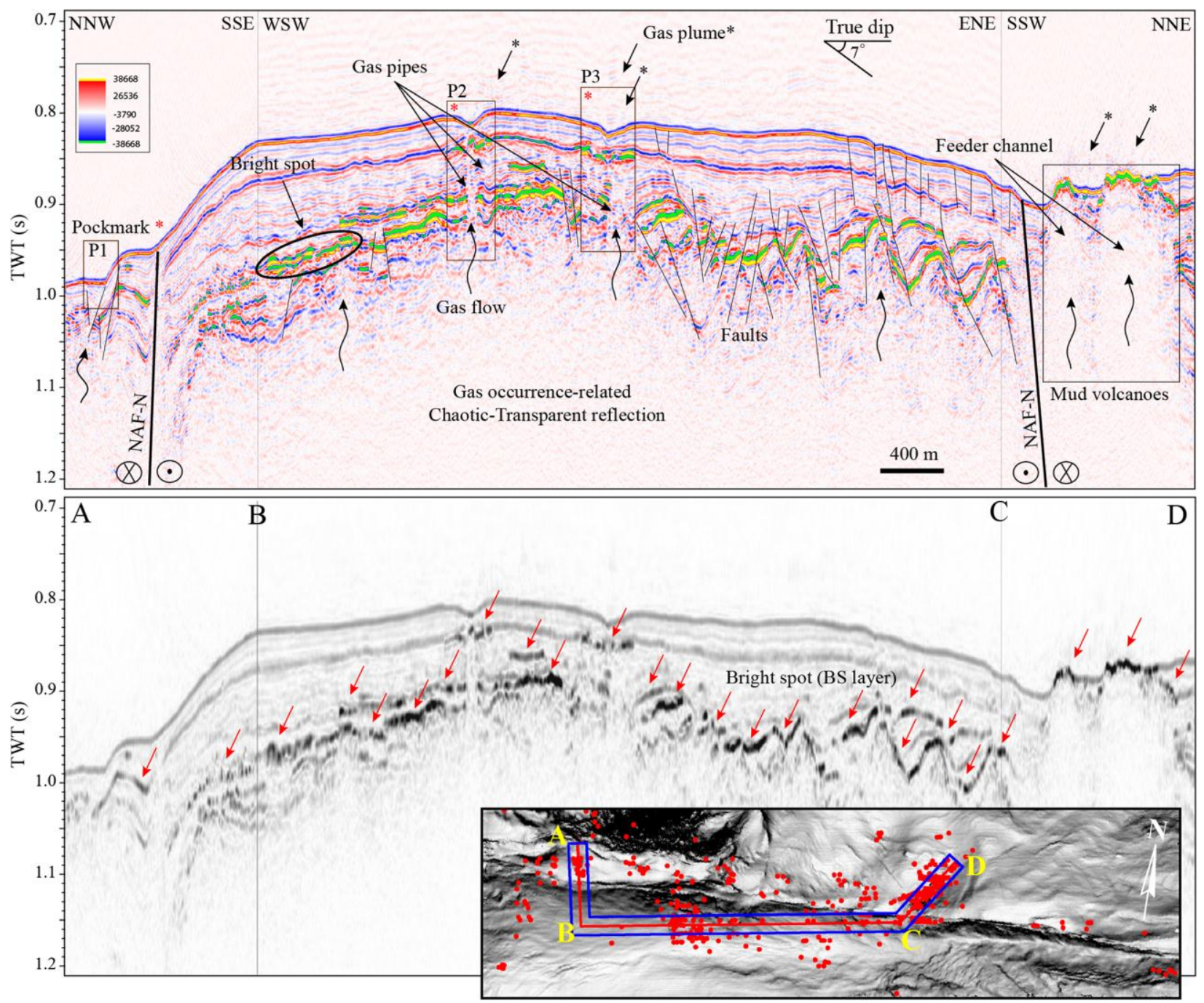


Fig. 8. a: Multichannel seismic response of the mud volcanoes "yellow line in B". White star-the mud volcano which is the closest to the NAF-N; Black star- the next mud volcano; Yellow starthe buried mud volcano. b: Time slice at $1.0 \mathrm{~s}$ "red line in A". Mud structures area shown by yellow dashed polygon without any strata reflectivity. c1-c2: Borders of the mud volcanoes below the seafloor (not to scale). They rise up through the seafloor.

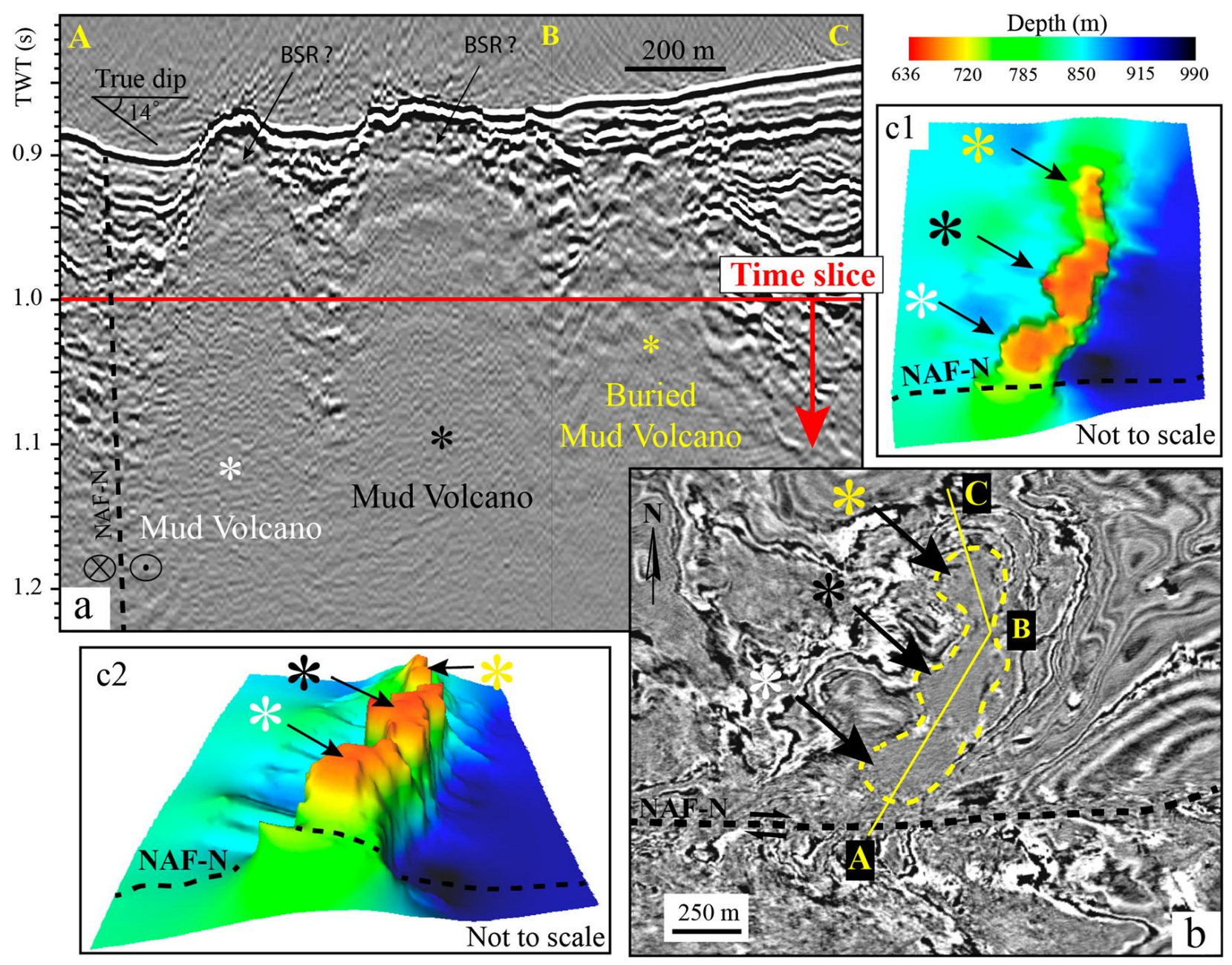


Fig. 9. "a2_b8" 2D seismic line (Fig. 1). a: Gas accumulates near the crest of anticlines. Cyan oval shows the possible pull-down effect of gas accumulation due to a decrease in velocity. The yellow box is the boundary of the 3D seismic area. b: Black patches on the envelope of seismic data identify bright spots which coincide with erosional surface in the Western High.

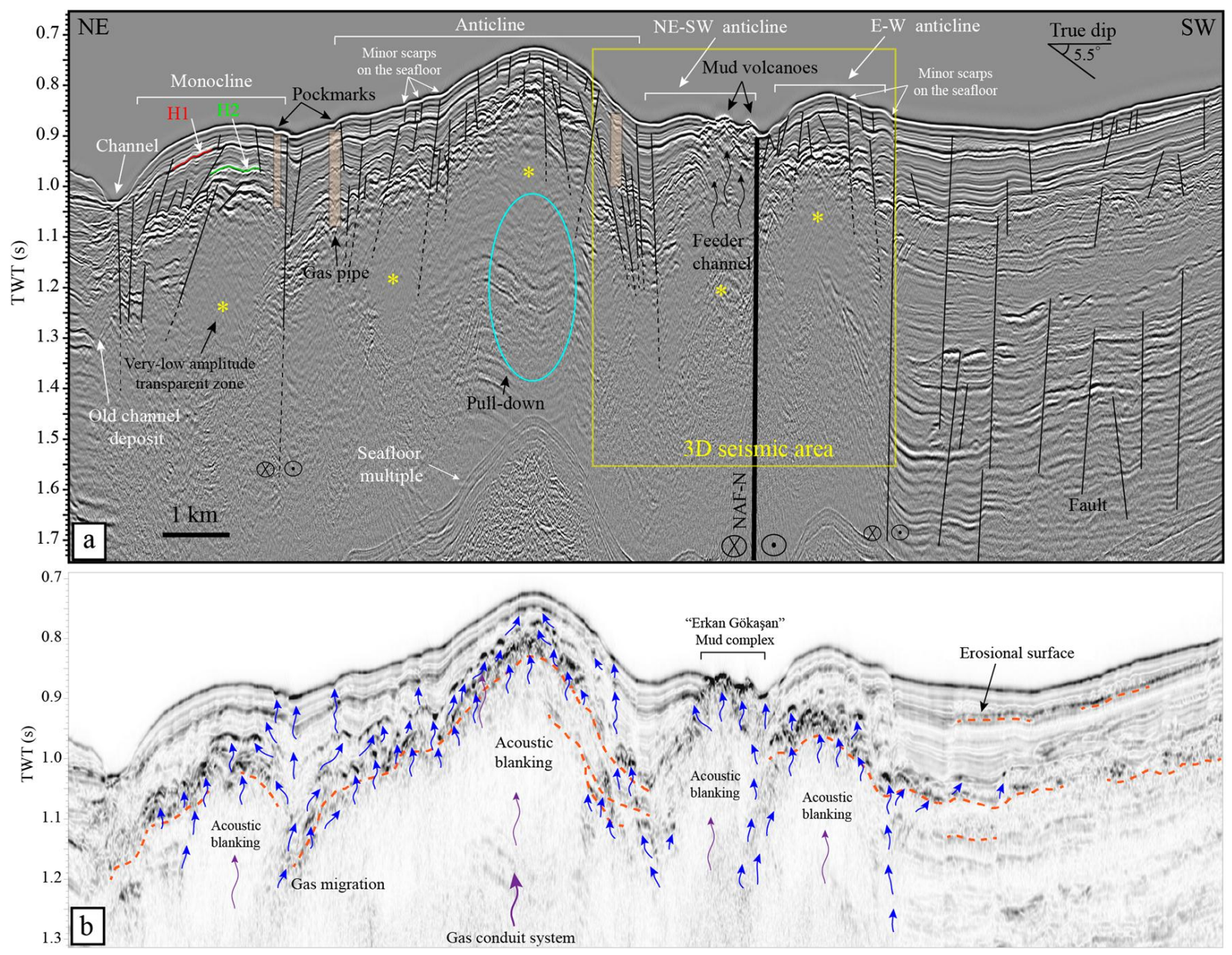


Fig. 10. Development of a pockmark formation: a) gas pipe rises towards the seafloor; b) fluidgas starts to accumulate beneath the seafloor; c) the overpressure causes the creation of temporal mound on the seafloor; d) fluid-gas eruption is carried out through the water column.
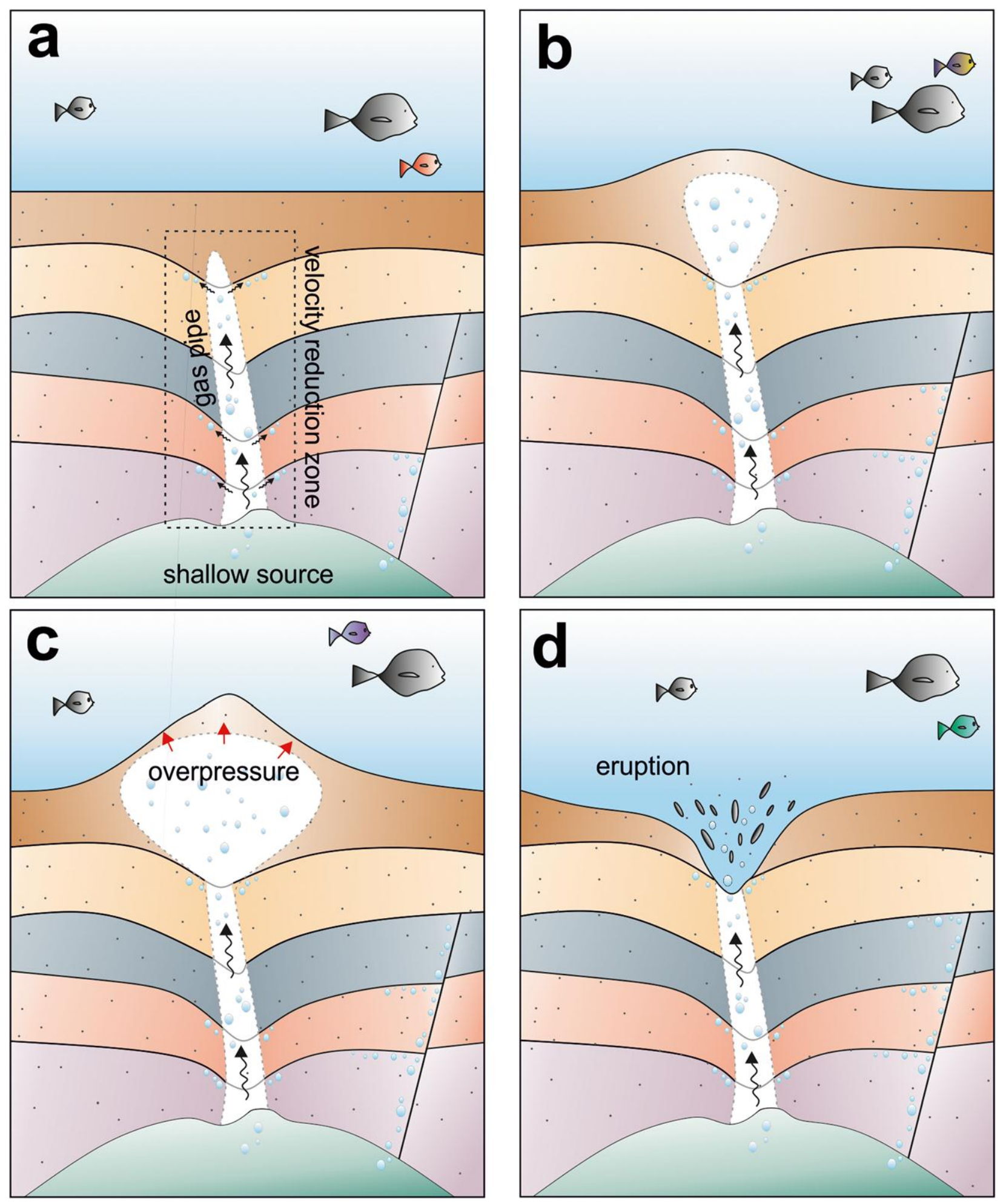
Fig. 11. Schematic relationship between the NAF-N and the formation of the mud volcanoes, as well as, gas conduit systems in the Western High. Thermogenic gas migrates from source/reservoir rock via the NAF-N and mud volcanoes to shallow depth. (ps: illustration is not to scale).

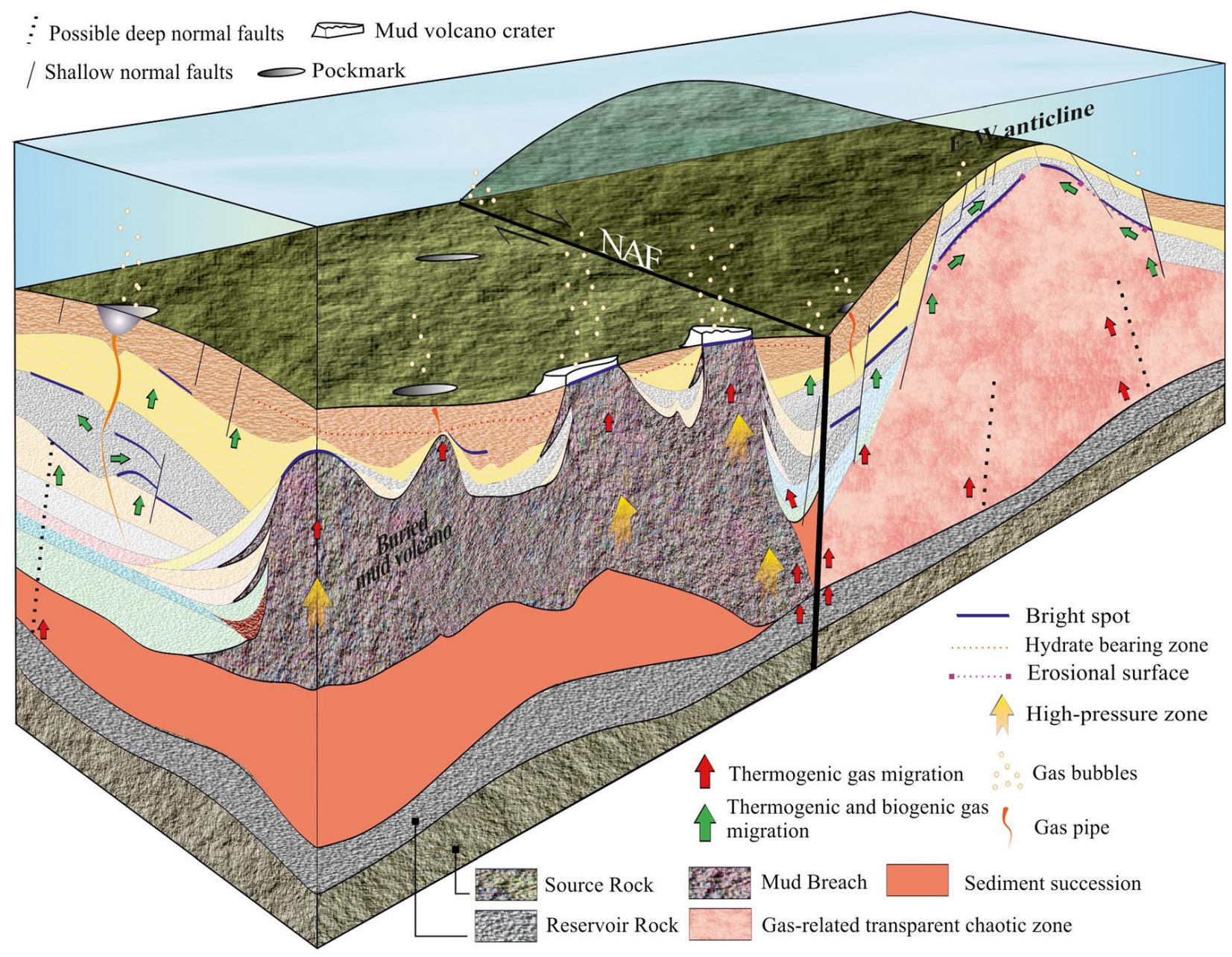

